\title{
Analysis of high mass resolution PTR-TOF mass spectra from 1,3,5-trimethylbenzene (TMB) environmental chamber experiments
}

\author{
M. Müller ${ }^{1, *}$, M. Graus ${ }^{1, * *}$, A. Wisthaler ${ }^{1, * * *}$, A. Hansel ${ }^{1}$, A. Metzger ${ }^{2}$, J. Dommen $^{3}$, and U. Baltensperger ${ }^{3}$ \\ ${ }^{1}$ Institute of Ion Physics and Applied Physics, University of Innsbruck, Innsbruck, Austria \\ ${ }^{2}$ Ionicon Analytik Gesellschaft m.b.H, Innsbruck, Austria \\ ${ }^{3}$ Paul Scherrer Institut, Villigen, Switzerland \\ * current address: DBFZ Deutsches BiomasseForschungsZentrum gemeinnützige GmbH, Leipzig, Germany \\ ** current address: Chemical Sciences Division, NOAA Earth System Research Laboratory, Boulder, CO, USA \\ ***** current address: NILU - Norwegian Institute of Air Research, Kjeller, Norway
}

Correspondence to: A. Hansel (armin.hansel@uibk.ac.at)

Received: 26 August 2011 - Published in Atmos. Chem. Phys. Discuss.: 16 September 2011

Revised: 19 December 2011 - Accepted: 10 January 2012 - Published: 18 January 2012

\begin{abstract}
A series of 1,3,5-trimethylbenzene (TMB) photooxidation experiments was performed in the $27-\mathrm{m}^{3}$ Paul Scherrer Institute environmental chamber under various $\mathrm{NO}_{\mathrm{x}}$ conditions. A University of Innsbruck prototype high resolution Proton Transfer Reaction Time-of-Flight Mass Spectrometer (PTR-TOF) was used for measurements of gas and particulate phase organics. The gas phase mass spectrum displayed $\sim 200$ ion signals during the TMB photo-oxidation experiments. Molecular formulas $\mathrm{C}_{\mathrm{m}} \mathrm{H}_{\mathrm{n}} \mathrm{N}_{\mathrm{o}} \mathrm{O}_{\mathrm{p}}$ were determined and ion signals were separated and grouped according to their $\mathrm{C}, \mathrm{O}$ and $\mathrm{N}$ numbers. This allowed to determine the time evolution of the $\mathrm{O}: \mathrm{C}$ ratio and of the average carbon oxidation state $\overline{\mathrm{OS}}_{\mathrm{C}}$ of the reaction mixture. Both quantities were compared with master chemical mechanism (MCMv3.1) simulations. The O:C ratio in the particle phase was about twice the $\mathrm{O}: \mathrm{C}$ ratio in the gas phase. Average carbon oxidation states of secondary organic aerosol (SOA) samples $\overline{\mathrm{OS}}_{\mathrm{C}}^{\mathrm{SOA}}$ were in the range of -0.34 to -0.31 , in agreement with expected average carbon oxidation states of fresh SOA $\left(\overline{\mathrm{OS}}_{\mathrm{C}}=-0.5-0\right)$.
\end{abstract}

\section{Introduction}

Volatile organic compounds (VOCs) are emitted into the atmosphere from various biogenic and anthropogenic sources. Atmospheric degradation processes of these VOCs yield a multitude of oxygenated products with lower or higher volatility compared to the parent compound. Photooxidation products of lower volatility may subsequently undergo transformation processes such as nucleation, conden- sation or reactive uptake on existing aerosols and form secondary organic aerosol (SOA). To better understand the formation, growth and fate of atmospheric SOA, detailed information about the many generations of gas-phase oxidation chemistry and the gas-particle partitioning is necessary. The current status of knowledge of formation, properties and impact of SOA was recently reviewed by Hallquist et al. (2009).

Recent studies account a large fraction of the total organic aerosol amount present in the atmosphere to SOA. In urban areas, more than $60 \%$ of the total organic aerosol mass may be attributed to SOA (Lanz et al., 2007). A significant fraction of urban SOA is formed by anthropogenic precursors (e.g. aromatic compounds such as benzene, toluene, xylenes and trimethylbenzenes), which are mostly emitted by fuel combustion and evaporation (Calvert et al., 2002; Kanakidou et al., 2005; Molina et al., 2007).

Jimenez et al. (2009) described a framework for the chemical evolution of organic aerosol using field and smog chamber data. High-Resolution Time-of-Flight Aerosol Mass Spectrometry (HR-TOF-AMS) was used for high time resolution measurements of the organic aerosol composition. The degree of oxidation was determined as the atomic O:C ratio of organic aerosol based on the study by Aiken et al. (2008).

Heald et al. (2010) found that the bulk composition of organic aerosol occupies a narrow range in the space of a Van Krevelen (H:C vs. O:C) diagram (Van Krevelen, 1950). Various laboratory and field experiments are included, all characterized by a slope of $\sim-1$.

Recently, Kroll et al. (2011) introduced the concept of an average carbon oxidation state $\overline{\mathrm{OS}}_{\mathrm{C}}$ as a metric to describe the chemistry of atmospheric organic aerosol. Together with

Published by Copernicus Publications on behalf of the European Geosciences Union. 
the carbon number $n_{\mathrm{C}}, \overline{\mathrm{OS}}_{\mathrm{C}}$ was used to constrain the composition of organic aerosol and to visualize key classes of atmospheric reactions.

Despite extensive efforts in recent years, significant uncertainties in the understanding of the photo-oxidation of aromatic compounds still remain. Photochemical reactions of aromatics are highly complex with numerous reaction pathways and a large number of products, most of which are photo-chemically active. Low concentrations of a large number of highly oxygenated compounds with widely varying properties make detection by conventional analytical methods difficult. Proton-Transfer-Reaction Mass Spectrometry (PTR-MS) has proven to be a quantitative method for VOC analysis (Lindinger et al, 1998; de Gouw et al., 2003). PTRMS has been applied in several environmental chamber studies for gas phase analysis (Wisthaler et al., 2001; D' Anna et al., 2005; Apel et al., 2008; Healy et al., 2008; Metzger et al., 2008; Perring et al., 2009). Nevertheless, the unit mass resolving power constricts the compound identification capability of conventional PTR-MS instruments. Recently, PTRMS has also been applied to the measurement of SOA composition (Hellen et al., 2008; Holzinger et al., 2010; Thornberry et al., 2009). Hellen et al. (2008) denuded the gas phase and directly evaporated the remaining particle phase. The other studies deployed an aerosol collection inlet to accumulate aerosol mass. The collected particles were thermally desorbed to volatilize the organic compounds which were subsequently detected by PTR-MS (Holzinger et al., 2010) or by a PTR Ion-Trap MS instrument (Thornberry et al., 2009).

In the last years, the PTR technology was enhanced by coupling the PTR ion source to a Time-of-Flight Mass Spectrometer (TOF-MS; Blake et al., 2004; Ennis et al., 2005; Tanimoto et al., 2007). However, poor instrumental sensitivities and mass resolving power brought only little increase in compound identification capabilities compared to conventional PTR-MS instruments. One of these instruments, the Chemical Ionization Reaction Time-of-Flight Mass Spectrometer (CIR-TOF-MS; Blake et al., 2006), measured the gas phase precursors to anthropogenic secondary organic aerosol from 1,3,5-trimethylbenzene (TMB) photo-oxidation (Wyche et al., 2009).

Recently, Graus et al. (2010) developed a PTR-TOF mass spectrometer with improved sensitivity and mass resolving power. A mass resolving power of up to 5000 and a mass uncertainty (accuracy and precision combined on a $95 \%$ confidence level) of $7.9 \mathrm{ppm}$ was reported. This instrument distinguishes most atmospherically relevant protonated isobaric VOCs and identifies the respective molecular formulas according to the measured accurate mass.

In the present study, we evaluate the performance of the high resolution PTR-TOF in a TMB smog chamber study. We determined the molecular formulas $\mathrm{C}_{m} \mathrm{H}_{n} \mathrm{~N}_{\mathrm{o}} \mathrm{O}_{\mathrm{p}}$ of TMB gas-phase photo-oxidation products and grouped them according to their $\mathrm{C}, \mathrm{O}$ and $\mathrm{N}$ numbers to get the total carbon mass balance and the time evolution of the total $\mathrm{O}: \mathrm{C}$ ratio during individual photo-oxidation experiments. As there are no other measurements available for these quantities, the results are discussed and compared to modeling results based on the master chemical mechanism (MCMv3.1; Bloss et al., 2005a,b). This information is then further used to represent the oxidative degradation of TMB in the $\overline{\mathrm{OS}}_{\mathrm{C}}-n_{\mathrm{c}}$ space. In addition, SOA samples were collected on filter substrates followed by thermo-desorption and PTR-TOF analysis. SOA $\mathrm{O}: \mathrm{C}$ ratios as well as average carbon oxidation states $\overline{\mathrm{OS}}_{\mathrm{C}}$ were determined at different desorption temperatures.

\section{Experimental and Methods}

\subsection{High Resolution PTR-TOF}

\subsubsection{Instrumental setup}

The high resolution PTR-TOF instrument (Graus et al., 2010) couples the advantages of a commercial PTR ion source (Ionicon Analytik, Innsbruck, Austria) with the advantages of a state-of-the-art high mass resolution time-of-flight mass spectrometer (Tofwerk AG, Thun, Switzerland).

PTR is a soft ionization technique with a low amount of fragmentation (Lindinger et al., 1998). As a consequence, most VOCs are detected in their protonated form containing the atomic composition information in the measured exact mass. Exceptions and their impact on the measurement of total carbon content, $\mathrm{O}: \mathrm{C}$ ratios and the carbon oxidation state are discussed in the Supplement.

In the current study, the prototype PTR-TOF mass spectrometer reached a mass resolving power of about 5000 (FWHM) combined with a mass accuracy of $20 \mathrm{ppm}$. These instrumental parameters allowed distinguishing compounds of identical nominal mass but different molecular formula. With a primary ion signal of about $4 \times 10^{5} \mathrm{cps}$, the instrument achieved a TMB sensitivity of $\sim 10 \mathrm{cpsppbv}^{-1}$ with a corresponding $3 \sigma$ limit of detection of $40 \mathrm{pptv}$ for oneminute integration time. Quantification of the target compounds of this study is described in the Supplement.

To gather more analytical information (see Supplement), the drift tube of the PTR-TOF instrument was operated in two E/N modes, at $135 \mathrm{Td}$ and $90 \mathrm{Td}$, respectively (with $\mathrm{E}$ as the electric field and $N$ as the neutral gas concentration; $\left.1 \mathrm{Td}=10^{-17} \mathrm{~V} \mathrm{~cm}^{2}\right)$. The corresponding drift tube voltages were $600 \mathrm{~V}\left(\mathrm{PTR}^{-T O_{600}}\right)$ and $400 \mathrm{~V}\left(\mathrm{PTR}-\mathrm{TOF}_{400}\right)$. The drift tube temperature was kept constant at $60{ }^{\circ} \mathrm{C}$ for both voltage settings. The PTR-TOF 600 and PTR-TOF 400 conditions were used to identify different fragmentation and clustering intensities of product ions observed during the photooxidation studies.

In addition to high resolution PTR-TOF measurements, TMB photo-oxidation experiments were also monitored with a commercial High Sensitivity PTR-MS instrument (Ionicon 
Analytik, Innsbruck, Austria) which deploys a quadrupole mass filter with unit mass resolution.

\subsubsection{Data acquisition and evaluation}

For PTR-TOF data acquisition, ions were pulsed into the TOF section every $32 \mu \mathrm{s}$. A Time-to-Digital Converter (TDC) recorded the arrival times of all ions detected by a Multichannel Plate (MCP). The time resolution of the TDC was $0.625 \mathrm{~ns}$, resulting in 49088 data bins per spectrum. The spectral information of 1875000 extractions was co-added to produce $1 \mathrm{~min}$ averaged spectra. During the smog chamber experiments a mass range from $\mathrm{m} / \mathrm{z} 0$ to $\mathrm{m} / \mathrm{z} 325$ was covered; during the SOA thermo-desorption experiments, the mass range was increased up to $m / z 600$ (44 $\mu$ s extraction time).

For data evaluation, a custom peak detection routine was used as described by Müller et al. (2010), enabling analysis of high mass resolved PTR-TOF time-series. Welldefined instrumental background ion peaks were used to obtain an accurate and precise mass scale on a one minute time scale. With this method the spectra could be integrated over $30 \mathrm{~min}$ periods without any loss of mass resolution. A peak search sub routine analyzed the integrated spectra of the entire photo-oxidation experiment and produced a list of all detected peaks. A superposition of Gaussian-like peak shapes was used for peak fitting. Finally, the peak intensities were TOF-MS duty cycle corrected and normalized to the primary ion signal. The high mass accuracy of the entire data acquisition and evaluation process allowed an elemental analysis of the whole spectra by determining the molecular formulas $\mathrm{C}_{\mathrm{m}} \mathrm{H}_{\mathrm{n}} \mathrm{N}_{\mathrm{o}} \mathrm{O}_{\mathrm{p}}$ using Elcomp ${ }^{\mathrm{TM}}$ chemistry software (ChemSW, Inc., USA). Based on MCM chemistry, nitrogen atom numbers o were limited to 0 and 1 . Identified ions could be separated and grouped according to their $\mathrm{C}, \mathrm{O}$ and $\mathrm{N}$ numbers. In addition, atomic $\mathrm{O}: \mathrm{C}$ ratios were calculated by dividing the total oxygen mole fractions (sum of all products multiplied with their corresponding oxygen number; ppbO) by the total carbon mole fraction (sum of all products in ppbv multiplied with their corresponding carbon number; ppbC). Further information about quantification can be found in the Supplement.

\subsection{Paul Scherrer Institute environmental chamber}

A series of photo-oxidation experiments was performed at the Paul Scherrer Institute (PSI) environmental chamber. It is a cubic $27-\mathrm{m}^{3}$ FEP fluorocarbon bag installed in a temperature controlled housing. Temperatures were stabilized at $20{ }^{\circ} \mathrm{C}$ during all experiments. The solar spectrum was simulated by four $4 \mathrm{~kW}$ xenon arc lamps. Details are described by Paulsen et al. (2005).

\subsubsection{Experiments}

A series of five experiments with initial TMB concentrations between 147 and $511 \mathrm{ppbv}$ and initial $\mathrm{NO}_{\mathrm{x}}$ concentrations ranging from 65 to $304 \mathrm{ppbv}$ were performed. Table 1 summarizes the initial conditions for all experiments. During experiment 4 , HONO was continuously added into the chamber to support $\mathrm{OH}$ formation.

\subsubsection{Master Chemical Mechanism simulations}

The Master Chemical Mechanism (MCMv3.1) was applied to simulate the TMB photo-oxidation experiments and to compare the modeled reaction products with the PTR-TOF results. Version 3.1 of the MCM uses kinetic and mechanistic data to construct degradation schemes for 18 aromatic VOCs, including 1,3,5-trimethylbenzene, according to Jenkin et al. (2003). A schematic representation of the $\mathrm{OH}$ initiated oxidation of TMB (first-generation oxidation products) as implemented in the MCMv3.1 (Bloss et al., 2005a, b; Metzger et al., 2008) is depicted in Fig. 1. According to current knowledge, $\mathrm{OH}$-reaction pathways include (i) $\mathrm{OH}$ addition leading to "phenolic", "peroxide-bicyclic" or "epoxyoxy" first generation/intermediate reaction products, and (ii) $\mathrm{H}$ abstraction at a methyl group. Products depicted in grey have expected yields $<1 \%$ for initial conditions of experiments $1 \mathrm{a}$ and $\mathrm{b}$.

Table 2 summarizes the MCMv3.1 simulated oxidation products for initial conditions of experiments $1 \mathrm{a}$ and $1 \mathrm{~b}$ with a yield $>1 \%$. All expected products are grouped according to their carbon number $n_{\mathrm{C}}$ and expected maximum mixing ratios are also given. Of the 17 predicted products, highest yields are expected for methylglyoxal and acetic nitric peroxyanhydride (PAN) with volume mixing ratios of $118 \mathrm{ppbv}$ and 65 ppbv, respectively.

The excellent agreement between MCMv3.1 predictions and measured TMB, $\mathrm{O}_{3}, \mathrm{NO}_{\mathrm{x}}$ is presented for various initial conditions by Metzger et al. (2008).

\subsubsection{Sampling and analysis of SOA}

In addition to gas phase measurements, SOA samples were collected on Teflon filters during experiment $1 \mathrm{~b}$ between 4.5 and $6 \mathrm{~h}$ of reaction time. A PTFE filter holder equipped with a Teflon filter of a pore size of $1.2 \mu \mathrm{m}$ and a diameter of $47 \mathrm{~mm}$ was installed into a copper sample line. To eliminate filter impurities from the aerosol sample, Teflon filters were pretreated by flushing with $51 \mathrm{~min}^{-1}$ of pure $\mathrm{N} 2$ at $140^{\circ} \mathrm{C}$ for $90 \mathrm{~min}$. Within $102 \mathrm{~min}$, a total volume of 10201 was sampled through the filter. After sampling, the filter was purged for one minute with pure nitrogen, sealed and kept in a freezer at $-20^{\circ} \mathrm{C}$ until analysis. Once the chamber experiment was completed, the complete SOA sample was put into a temperature controlled $1 / 4^{\prime \prime}$ passivated stainless steel tube (Silco-Steel®, Restek, Bellefonte, USA). This desorption unit was flushed with $100 \mathrm{sccm}$ of pure nitrogen and sampled with the PTR-TOF. After sampling at ambient temperature for $10 \mathrm{~m}$, the desorption unit was heated up stepwise to $75^{\circ} \mathrm{C}, 100{ }^{\circ} \mathrm{C}$ and $125^{\circ} \mathrm{C}$ with transient times of less 


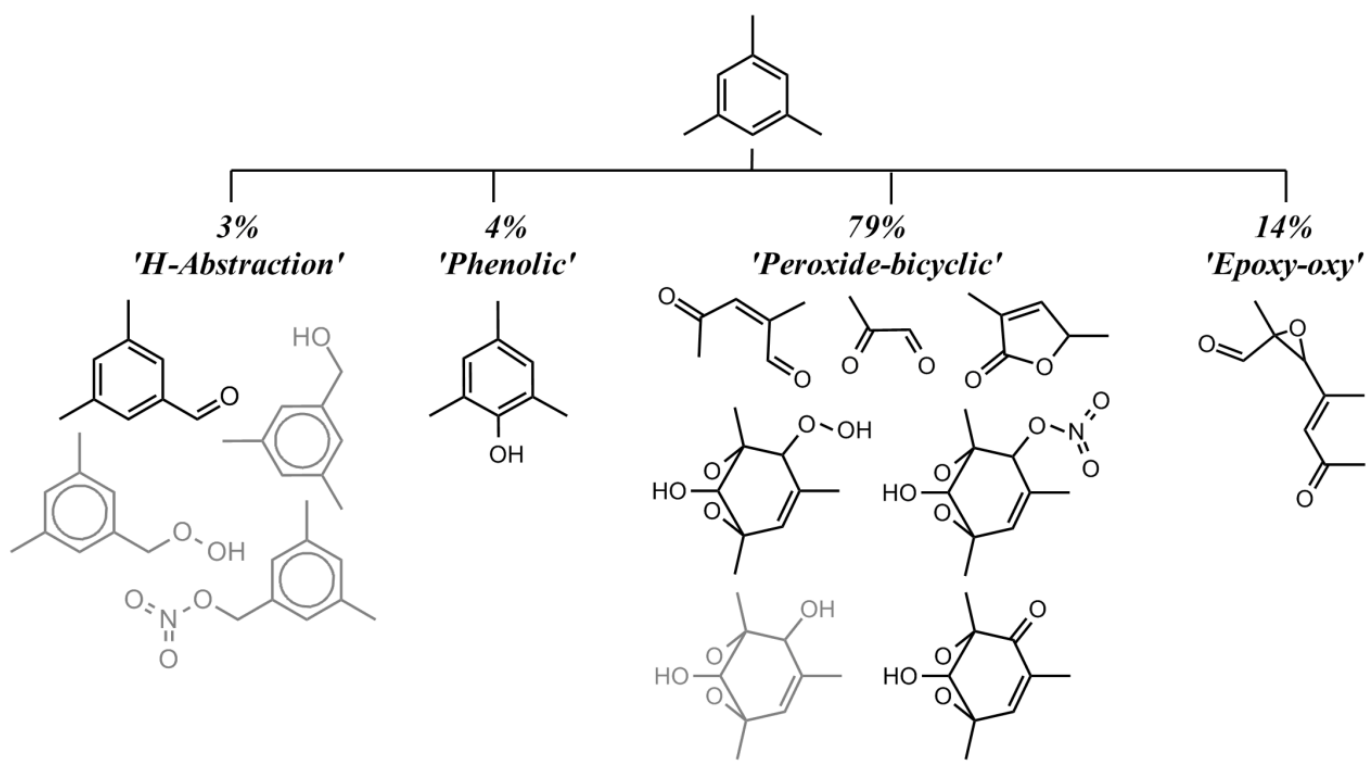

Fig. 1. Schematic representation of the TMB oxidation pathways in the presence of $\mathrm{NO}_{\mathrm{x}}$ as implemented in the MCMv3.1 (first generation products only).

Table 1. Initial conditions of all conducted TMB experiments and PTR-TOF instrumental settings. Experimental conditions varied from about $150 \mathrm{ppbv}$ to $510 \mathrm{ppbv} \mathrm{TMB}$ at $\mathrm{VOC} / \mathrm{NO}_{\mathrm{x}}$ ratios between 0.5 and 2 . During experiment 4 , HONO was continuously added to the chamber to support $\mathrm{OH}$ formation.

\begin{tabular}{|c|c|c|c|c|c|c|c|}
\hline $\begin{array}{l}\text { Experiment } \\
\text { \# }\end{array}$ & $\begin{array}{r}\text { TMB } \\
{[\mathrm{ppbv}]}\end{array}$ & $\begin{array}{r}\mathrm{NO} \\
{[\mathrm{ppbv}]}\end{array}$ & $\begin{array}{r}\mathrm{NO}_{2} \\
{[\mathrm{ppbv}]}\end{array}$ & $\begin{array}{r}\text { Relative } \\
\text { Humidity [\%] }\end{array}$ & $\begin{array}{r}\text { PTR-TOF Drift Tube } \\
\text { E/N [Td] }\end{array}$ & $\begin{array}{l}\text { PTR-TOF } \\
\text { Mode }\end{array}$ & $\begin{array}{r}\text { lights on } \\
{[\mathrm{min}]}\end{array}$ \\
\hline $1 \mathrm{a}$ & 511 & 135 & 129 & 52 & 135 & PTR-TOF 600 & 520 \\
\hline $1 b$ & 505 & 135 & 130 & 53 & 90 & PTR-TOF 400 & 471 \\
\hline 2 & 164 & 35 & 30 & 49 & 135 & PTR-TOF $_{600}$ & 442 \\
\hline 3 & 148 & 134 & 129 & 48 & 135 & PTR-TOF $_{600}$ & 599 \\
\hline 4 & 152 & \multicolumn{2}{|c|}{$\mathrm{HONO} \sim 10 \mathrm{ppbv}$} & 62 & 135 & PTR-TOF $_{600}$ & 488 \\
\hline
\end{tabular}

than $60 \mathrm{~s}$ holding each temperature for $10 \mathrm{~m}$. Finally, one further temperature increase to $140^{\circ} \mathrm{C}$ was performed to test whether the previous desorption steps had covered a wide enough temperature range and to clean the desorption unit before cooling it down. For data analysis of the SOA desorption spectra a uniform sensitivity was assumed. All detected ions were quantified using the acetone sensitivity. Blank filter spectra were subtracted from the aerosol filter spectra for each desorption temperature.

\subsection{Van Krevelen diagram}

The Van Krevelen diagram (Van Krevelen, 1950) was developed to illustrate chemical composition changes by cross plotting O:C and $\mathrm{H}: \mathrm{C}$ ratios. In the Van Krevelen diagram, the addition of functional groups is characterized by different slopes, e.g. the addition of an alcohol or peroxide results in a slope of 0 , the addition of a carboxylic acid results in a slope of -1 and the addition of a ketone or aldehyde results in a slope of -2 . The ratios of O:C and $\mathrm{H}: \mathrm{C}$ can be directly measured by means of high resolution PTR-TOF. Van Krevelen diagrams have recently been used as a diagnostic tool for the analysis of organic aerosols by Heald et al. (2010).

\subsection{Average Carbon oxidation state $\overline{\mathrm{OS}}_{\mathrm{C}}$}

The concept of the average carbon oxidation state, $\overline{\mathrm{OS}}_{\mathrm{C}}$, with a focus on organic aerosol, was recently discussed by Kroll et al. (2011). Therefore only a brief introduction will be given here.

The oxidation state of carbon is defined as the theoretical charge of a carbon atom that loses all electrons in bonds with more electronegative atoms and gains all electrons in bonds with less electronegative atoms.

$\overline{\mathrm{OS}}_{\mathrm{C}}$ can be calculated as the sum over all non-carbon elements $\mathrm{i}$ of the oxidation associated with element $\mathrm{i}\left(\mathrm{OS}_{\mathrm{i}}\right)$ 
Table 2. Overview of all MCMv3.1 predicted TMB degradation products with a molar yield $>1 \%$. The products are grouped according to their number of carbon atoms $n_{\mathrm{C}}$. The predicted maximum volume mixing ratio (max. VMR) within the first $10 \mathrm{~h}$ of reaction time during experiment $1 \mathrm{a}$ is also shown.

\begin{tabular}{|c|c|c|c|c|}
\hline$\# \mathrm{C}$ & MCMv3.1 products & $\begin{array}{l}\text { molecular } \\
\text { formula }\end{array}$ & $\begin{array}{l}\max . \text { VMR } \\
{[\mathrm{ppbv}]}\end{array}$ & $\begin{array}{l}\text { total } \\
{[\mathrm{ppbC}]}\end{array}$ \\
\hline 1 & formaldehyde & $\mathrm{CH}_{2} \mathrm{O}$ & 21 & 21 \\
\hline 2 & acetic nitric peroxyanhydride (PAN) & $\mathrm{C}_{2} \mathrm{H}_{3} \mathrm{NO}_{5}$ & 65 & 130 \\
\hline 3 & methylglyoxal & $\mathrm{C}_{3} \mathrm{H}_{4} \mathrm{O}_{2}$ & 118 & 354 \\
\hline 5 & methylfurandione & $\mathrm{C}_{5} \mathrm{H}_{4} \mathrm{O}_{3}$ & 6 & 30 \\
\hline 6 & $\begin{array}{l}\text { dimethylfuranone } \\
\text { methyloxopentenal } \\
\text { methyloxopentenoic acid } \\
\text { acetylmethyloxiranecarbaldehyde } \\
\text { oxopropanyl oxopropanoate } \\
\text { hydroperoxyhydroxydimethyldihydrofuranone } \\
\text { methyloxopentenyloxiranecarbaldehyde } \\
\text { methyloxopentenoic nitric peroxyanhydride } \\
\text { hydroperoxydimethyloxotetrahydrofuranyl nitrate } \\
\text { nitric oxopropanoyloxypropanoic peroxyanhydride }\end{array}$ & $\begin{array}{l}\mathrm{C}_{6} \mathrm{H}_{8} \mathrm{O}_{2} \\
\mathrm{C}_{6} \mathrm{H}_{8} \mathrm{O}_{2} \\
\mathrm{C}_{6} \mathrm{H}_{8} \mathrm{O}_{3} \\
\mathrm{C}_{6} \mathrm{H}_{8} \mathrm{O}_{3} \\
\mathrm{C}_{6} \mathrm{H}_{8} \mathrm{O}_{4} \\
\mathrm{C}_{6} \mathrm{H}_{10} \mathrm{O}_{5} \\
\mathrm{C}_{6} \mathrm{H}_{10} \mathrm{O}_{5} \\
\mathrm{C}_{6} \mathrm{H}_{7} \mathrm{NO}_{6} \\
\mathrm{C}_{6} \mathrm{H}_{9} \mathrm{NO}_{7} \\
\mathrm{C}_{6} \mathrm{H}_{7} \mathrm{NO}_{8}\end{array}$ & $\begin{array}{l}41 \\
15 \\
6 \\
12 \\
51 \\
9 \\
8 \\
31 \\
9 \\
7\end{array}$ & 1134 \\
\hline 9 & $\begin{array}{l}\text { hydroxytrimethyldioxabicyclooctenone } \\
\text { hydroperoxytrimethyldioxabicyclooctenol } \\
\text { hydroxytrimethyldioxabicyclooctenyl nitrate }\end{array}$ & $\begin{array}{l}\mathrm{C}_{9} \mathrm{H}_{12} \mathrm{O}_{4} \\
\mathrm{C}_{9} \mathrm{H}_{14} \mathrm{O}_{5} \\
\mathrm{C}_{9} \mathrm{H}_{13} \mathrm{NO}_{6}\end{array}$ & $\begin{array}{l}10 \\
12 \\
14\end{array}$ & 324 \\
\hline
\end{tabular}

multiplied with the molar ratio of element $\mathrm{i}$ to carbon $\left(n_{\mathrm{i}} / n_{\mathrm{c}}\right.$; Eq. 1).

$\overline{\mathrm{OS}}_{\mathrm{C}}=\sum_{\mathrm{i}} \mathrm{OS}_{\mathrm{i}} \frac{n_{\mathrm{i}}}{n_{\mathrm{c}}}$

In a closed system, $\overline{\mathrm{OS}}_{\mathrm{C}}$ increases as oxidation progresses. The highest carbon oxidation state that can be reached is the complete oxidation towards $\mathrm{CO}_{2}\left(\overline{\mathrm{OS}}_{\mathrm{C}}=4\right)$.

VOCs and organic aerosol in the atmosphere mainly consist of carbon $(\mathrm{C})$, hydrogen $(\mathrm{H})$ and oxygen $(\mathrm{O})$ atoms. According to the definition of the $\overline{\mathrm{OS}}_{\mathrm{C}}, \mathrm{H}$ decreases the $\overline{\mathrm{OS}}_{\mathrm{C}}$ by 1 and $\mathrm{O}$ increases the $\overline{\mathrm{OS}}_{\mathrm{C}}$ by 2 for oxygen-containing functional groups like alcohols, carbonyls, carboxylic acids, ethers and esters. Therefore, if the abundance of other elements is negligible, Eq. (1) can often be simplified to:

$\overline{\mathrm{OS}}_{\mathrm{C}} \sim 2 \frac{\mathrm{O}}{\mathrm{C}}-\frac{\mathrm{H}}{\mathrm{C}}$

Peroxide groups that are expected to be formed during the TMB photo-oxidation experiments, will introduce a deviation from Eq. (2) since their $\mathrm{O}$ atoms have an oxidation state of -1 . Nevertheless, Kroll et al. (2011) discussed that even for peroxide-rich systems (e.g. isoprene ozonolysis), Eq. (2) yields an $\overline{\mathrm{OS}}_{\mathrm{C}}$ that is within 0.1 of the exact value from equation (1). As the nitrogen content is expected to be low compared to the carbon content of the system $(\mathrm{N} / \mathrm{C}<0.07$, MCMv3.1 prediction) only a low deviation due to nitrogen can be expected. Therefore all results will be calculated using the simplified Eq. (2).

\section{Results and discussion}

\subsection{Comparison of high resolution PTR-TOF 400 , PTR- TOF $_{600}$ and conventional PTR-MS results}

The improved analytical specificity of the high resolution PTR-TOF as compared to a conventional quadrupole-based PTR-MS instrument is exemplified in Fig. 2. While the latter detects only one ion signal at $\mathrm{m} / \mathrm{z} 113$, the PTR-TOF detected three isobars $\left(\mathrm{C}_{5} \mathrm{H}_{5} \mathrm{O}_{3}^{+}, \mathrm{C}_{6} \mathrm{H}_{9} \mathrm{O}_{2}^{+}\right.$, and $\mathrm{C}_{7} \mathrm{H}_{13} \mathrm{O}^{+}$; respectively $\mathrm{m} / \mathrm{z} 113.023, \mathrm{~m} / \mathrm{z} 113.060$ and $\mathrm{m} / \mathrm{z} 113.096)$. Accurate elemental composition information is essential to conduct the analyses presented herein.

Further analytical information (e.g. identification of fragment ions) can be gained by operating the PTR-TOF at different drift voltage settings. Figure 3 depicts the time evolution of selected ion signals as measured during experiment 1a $\left(\mathrm{PTR}-\mathrm{TOF}_{600}\right)$ and experiment $1 \mathrm{~b}\left(\mathrm{PTR}-\mathrm{TOF}_{400}\right)$. Panel (a) demonstrates the agreement in the quantification of the TMB degradation with both instrument settings PTR$\mathrm{TOF}_{400}$ and PTR-TOF 600 from the experiments $1 \mathrm{~b}$ and $1 \mathrm{a}$, respectively. Panel (b) shows the time evolution of the primary degradation product methylglyoxal (measured on $m / z 73.029$, plus fragment at $m / z 45.033$ ). Panel (c) depicts 
Table 3. List of ion sum formulas of the major TMB degradation products measured during experiments $1 \mathrm{a}$ and $1 \mathrm{~b}$ within $7 \mathrm{~h}$ of reaction. The measured maximum volume mixing ratio (max. VMR) is also given.

\begin{tabular}{|c|c|c|c|c|}
\hline $\begin{array}{l}\text { Ionic } \\
\text { formula }\end{array}$ & $m / z$ & $\begin{array}{l}\text { neutral } \\
\text { precursor }\end{array}$ & $\begin{array}{l}\max . \text { VMR } \\
\text { (ppbv) }\end{array}$ & $\begin{array}{l}\text { PTR-TOF } \\
\text { mode }(V)\end{array}$ \\
\hline $\mathrm{C}_{3} \mathrm{H}_{5} \mathrm{O}_{2}$ & $\begin{array}{l}73.028 \\
45.033\end{array}$ & methylglyoxal & 140 & $600+400$ \\
\hline $\mathrm{C}_{2} \mathrm{H}_{5} \mathrm{O}_{2}$ & $\begin{array}{l}61.028 \\
43.017\end{array}$ & $\begin{array}{l}\text { potential artifact } \\
\text { acetic acid } \\
\text { hydroxy acetaldehyde }\end{array}$ & 85 & 400 \\
\hline $\mathrm{NO}_{2}$ & 45.992 & $\begin{array}{l}\text { nitrate fragment } \\
\text { e.g. PAN }\end{array}$ & $\begin{array}{l}92 \\
39\end{array}$ & $\begin{array}{l}600 \\
400\end{array}$ \\
\hline $\mathrm{C}_{2} \mathrm{H}_{5} \mathrm{O}_{3}$ & 77.024 & PAN fragment & $\begin{array}{l}5 \\
59\end{array}$ & $\begin{array}{l}600 \\
400\end{array}$ \\
\hline $\mathrm{C}_{6} \mathrm{H}_{9} \mathrm{O}_{2}$ & 113.060 & $\begin{array}{l}\text { dimethylfuranone } \\
\text { methyloxopentenal }\end{array}$ & 24 & $600+400$ \\
\hline $\mathrm{C}_{6} \mathrm{H}_{9} \mathrm{O}_{3}$ & $\begin{array}{l}129.053 \\
111.045\end{array}$ & $\begin{array}{l}\text { methyloxopentenoic acid } \\
\text { acetylmethyloxiranecarbaldehyde }\end{array}$ & 17 & $600+400$ \\
\hline $\mathrm{C}_{5} \mathrm{H}_{5} \mathrm{O}_{3}$ & 113.024 & methylfurandione & 13 & $600+400$ \\
\hline $\mathrm{C}_{2} \mathrm{H}_{7} \mathrm{O}$ & $\begin{array}{l}47.048 \\
65.062\end{array}$ & e.g. ethanol & 12 & $600+400$ \\
\hline $\mathrm{C}_{4} \mathrm{H}_{7} \mathrm{O}_{2}$ & 87.045 & possible fragment & $\begin{array}{l}12 \\
6\end{array}$ & $\begin{array}{l}600 \\
400\end{array}$ \\
\hline $\mathrm{CH}_{3} \mathrm{O}_{2}$ & 47.013 & e.g. formic acid & 9 & 600 \\
\hline $\mathrm{C}_{9} \mathrm{H}_{13} \mathrm{O}$ & 137.094 & trimethylphenol & 9 & $600+400$ \\
\hline $\mathrm{CH}_{5} \mathrm{O}$ & $\begin{array}{l}33.034 \\
51.047\end{array}$ & e.g. methanol & 8 & $600+400$ \\
\hline $\mathrm{C}_{5} \mathrm{H}_{9} \mathrm{O}_{2}$ & 101.060 & unidentified & 7 & $600+400$ \\
\hline
\end{tabular}

the results for $\mathrm{C}_{6} \mathrm{H}_{9} \mathrm{O}_{2}^{+}$(according to MCMv3.1 dimethylfuranone and methyloxopentenal), measured on $\mathrm{m} / z 113.060$ plus its hydrate on $\mathrm{m} / z$ 131.070. Panel (d) depicts the time evolution of $\mathrm{C}_{9} \mathrm{H}_{11} \mathrm{O}^{+}(\mathrm{m} / \mathrm{z}, 135.080)$ and panel (e) shows the time series of $\mathrm{C}_{9} \mathrm{H}_{13} \mathrm{O}^{+}(\mathrm{m} / z$ 137.096), which correspond to 3,5-dimethylbenzaldehyde and 2,4,6-trimethylphenol, respectively. PTR-TOF data measured in the two operation modes compare very well, demonstrating the high reproducibility of the initial conditions of experiments $1 \mathrm{a}$ and $1 \mathrm{~b}$ and indicating that quantification of the given signals is not complicated by ionic fragmentation or signal overlaps. Panel (f) shows the time evolution of the $\mathrm{C}_{2} \mathrm{H}_{5} \mathrm{O}_{3}^{+}$ion which is formed upon protonation of PAN and subsequent reaction of protonated PAN with water (Hansel and Wisthaler, 2000). The $\mathrm{C}_{2} \mathrm{H}_{5} \mathrm{O}_{3}^{+}$ion yield from PAN increases when lowering the drift tube voltage. Differences in PTR-TOF 600 and PTR$\mathrm{TOF}_{400}$ data can be used for compound identification.
During the experiments, 13 possible products with a molar yield $>1 \%$ were detected. Table 3 displays the measured ionic formulas, potential neutral precursors, and the observed maximum volume mixing ratios (VMR). Methylglyoxal was detected with a maximum VMR of 140 ppbv. This is in fairly good agreement with the expected formation of $118 \mathrm{ppbv}$ of methylglyoxal derived from MCMv3.1 simulations.

PAN is difficult to quantify by PTR-MS. Major product ions are $\mathrm{NO}_{2}^{+}$and $\mathrm{C}_{2} \mathrm{H}_{5} \mathrm{O}_{3}^{+}$, with $\mathrm{NO}_{2}^{+}$being an unspecific fragment from many nitro-group containing compounds. Relative $\mathrm{NO}_{2}^{+}$and $\mathrm{C}_{2} \mathrm{H}_{5} \mathrm{O}_{3}^{+}$yields from PAN were not determined in the current study. According to the PTR$\mathrm{TOF}_{400}$ data, the PAN mixing ratio can be constrained between 44 ppbv $\left(\mathrm{C}_{2} \mathrm{H}_{5} \mathrm{O}_{3}^{+}\right.$contribution only; Fig. 3f) and 98 ppbv (sum of $\mathrm{C}_{2} \mathrm{H}_{5} \mathrm{O}_{3}^{+}$and $\mathrm{NO}_{2}^{+}$). The MCMv3.1 derived formation of $65 \mathrm{ppbv}$ of PAN falls between these boundaries.

The $\mathrm{C}_{2} \mathrm{H}_{5} \mathrm{O}_{2}^{+}$signal, possibly formed from acetic acid or hydroxyacetaldehyde, shows a rather linear increase during 


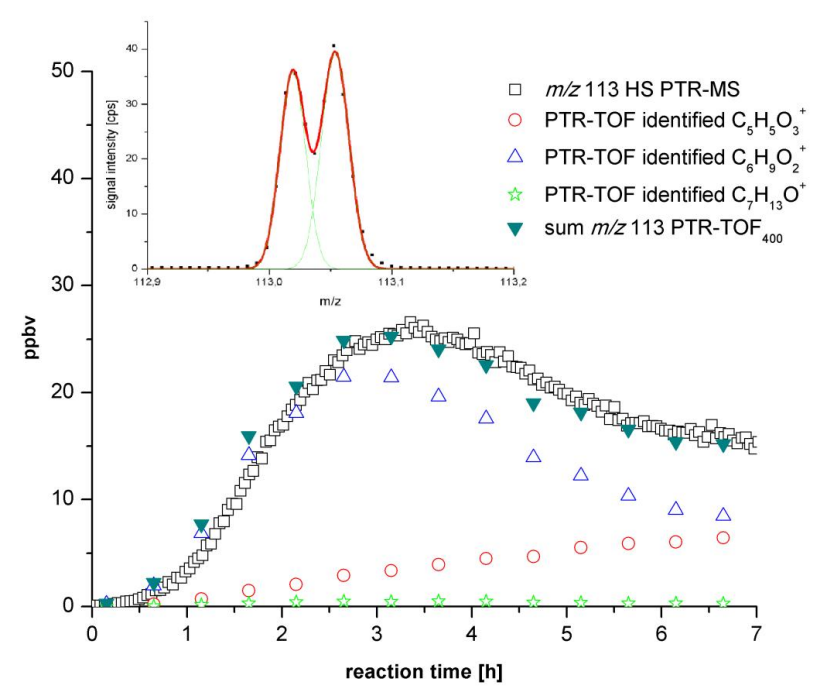

Fig. 2. Time evolution of highly mass resolved $\mathrm{PTR}-\mathrm{TOF}_{400}$ data of three $m / z, 113$ isobars $\left(\mathrm{C}_{5} \mathrm{H}_{5} \mathrm{O}_{3}^{+}, \mathrm{C}_{6} \mathrm{H}_{9} \mathrm{O}_{2}^{+}\right.$, and $\mathrm{C}_{7} \mathrm{H}_{13} \mathrm{O}^{+}$detected at $\mathrm{m} / \mathrm{z} 113.023, \mathrm{~m} / \mathrm{z}, 113.060$ and $\mathrm{m} / \mathrm{z}, 113.096$, respectively) compared to unit mass resolution data from a HS PTR-MS instrument. The inset illustrates the raw spectrum after $7 \mathrm{~h}$ of reaction time between $m / z, 112.9$ and $m / z 113.2$ (black squares), the fits of each detected ion (green line) and the superposition of the total ion signal (red line).

the whole experiment reaching more than $80 \mathrm{ppbv}$ at the end of the experiment. Acetic acid is a common artifact in smog chamber studies. A blank experiment in which the chamber was irradiated in the absence of any reagent produced $\mathrm{C}_{2} \mathrm{H}_{5} \mathrm{O}_{2}^{+}$concentrations between 10 and 20 ppbv. MCMv3.1 chemistry expects only about 2 ppbv of acetic acid being formed for the conditions of experiments $1 \mathrm{a}$ and $1 \mathrm{~b}$. A significant fraction of the $\mathrm{C}_{2} \mathrm{H}_{5} \mathrm{O}_{2}^{+}$signal may thus be due to off-gassing from the chamber walls which was later also detected by ion chromatography measurements (Praplan et al., 2012).

MCMv3.1 chemistry expects the formation of dimethylfuranone and methyloxopentenal. Only $24 \mathrm{ppbv}$ of the corresponding $\mathrm{C}_{6} \mathrm{H}_{9} \mathrm{O}_{2}^{+}$ions were detected, which is less than half of the MCMv3.1 predictions. The second significant $\mathrm{C}_{6}$ contribution, $\mathrm{C}_{6} \mathrm{H}_{9} \mathrm{O}_{3}$ (MCMv3.1: methyloxopentenoic acid and acetylmethyloxiranecarbaldehyde) was detected with a mixing ratio of $17 \mathrm{ppbv}$. The observed levels perfectly agree with the MCMv3.1 model output.

The formation of $\mathrm{C}_{4} \mathrm{H}_{7} \mathrm{O}_{2}^{+}$and $\mathrm{C}_{5} \mathrm{H}_{9} \mathrm{O}_{2}^{+}$ions cannot be explained by MCMv3.1 chemistry. These ions arise either from unknown reaction products or from fragmentation of higher-molecular weight products.

A more detailed analysis of mass spectra produced for both PTR-TOF 600 and PTR-TOF 400 conditions indicates that no significant amounts of nitrates and peroxyanhydrides (with the exception of PAN) were formed (see Supplement).

\subsection{High mass resolved product analysis by PTR-TOF}

During the TMB degradation experiments about 200 peaks were detected and identified $\left(\mathrm{C}_{\mathrm{m}} \mathrm{H}_{\mathrm{n}} \mathrm{N}_{\mathrm{o}} \mathrm{O}_{\mathrm{p}}\right)$ in the gas-phase PTR-TOF mass spectrum. Figure 4 a depicts the total amount of carbon of all TMB degradation products measured during experiment $1 \mathrm{a}\left(\mathrm{PTR}-\mathrm{TOF}_{600}\right.$ condition). The measurements are compared to the MCMv3.1 model output for which chamber dilution was corrected and the products $\mathrm{CO}$ and $\mathrm{CO}_{2}$ were neglected. The time trend is very similar and measured carbon mixing ratios were only about $18 \%$ below the MCMv3.1 model output after $7 \mathrm{~h}$. This discrepancy may be explained by the fact that neutral C-containing fragments are formed upon protonation (e.g. from PAN-type compounds or esters, see Supplement) in the PTR-TOF. Carbon-containing neutral fragments are not accounted for in a mass spectrometric analysis. In the model low volatility products which may partition into the particle phase are simulated as gas phase products and thus included in the carbon balance. However, from the known aerosol yield of TMB this would only contribute about $2 \%$ to the carbon balance. Wall losses of compounds may also decrease the measured amount of carbon but is expected to be small for compounds lower than C9 (Matsunaga and Zieman, 2010).

Figure $4 \mathrm{~b}$ compares the measured carbon volume mixing ratios of products with MCM calculations for one high concentration experiment with $\mathrm{TMB} / \mathrm{NO}_{\mathrm{x}}=1.9$, two low concentration experiments with $\mathrm{TMB} / \mathrm{NO}_{\mathrm{x}}=0.6$ and $\mathrm{TMB} / \mathrm{NO}_{\mathrm{x}} \approx 2.5$, and one low concentration experiment with HONO addition. The PTR-TOF measures on average only $15 \%$ less carbon than modeled (slope of linear regression $=0.85$ ). All data lie within the boundary lines given by slopes of 0.70 and 0.95 . This finding suggests that PTR-TOF detects most of the carbon of the photo-oxidation products although it is difficult or impossible to individually identify nitrates, "peroxide-bicyclic" and "epoxy-oxy" compounds or other functionalized species.

Figure 5 depicts the time evolution of $\mathrm{C}_{2}, \mathrm{C}_{3}, \mathrm{C}_{4}, \mathrm{C}_{5}, \mathrm{C}_{6}$ and $\mathrm{C}_{9}$ TMB degradation products as measured by PTRTOF (PTR-TOF 600 and PTR-TOF 400 ) and modeled using MCMv3.1 chemistry (Metzger et al., 2008). Only small amounts of $\mathrm{C}_{1}, \mathrm{C}_{7}$, and $\mathrm{C}_{8}$ compounds were measured (maximum $11 \mathrm{ppbC}, 34 \mathrm{ppbC}$ and $44 \mathrm{ppbC}$, respectively) which have thus not been included in the figure.

About 2-3 times more $\mathrm{C}_{2}$ products are measured than modeled (panel (a)). $\mathrm{C}_{2} \mathrm{H}_{5} \mathrm{O}_{2}^{+}$(acetic acid or hydroxyacetaldehyde) was identified by PTR-TOF as the dominating compound. As discussed above, roughly $20-40 \mathrm{ppbC}$ of acetic acid can be attributed to wall off-gassing and the MCMv3.1 model expects only low acetic acid concentrations from TMB degradation $(<5 \mathrm{ppbC})$. This implies that the $\mathrm{C}_{2} \mathrm{H}_{5} \mathrm{O}_{2}^{+}$ion arises from hydroxyacetaldehyde or is an ionic fragment. The MCMv3.1 $\mathrm{C}_{2}$-signal is dominated by up to $130 \mathrm{ppbC}$ of PAN. The contribution from PAN may be significantly underestimated in the experimental data. 

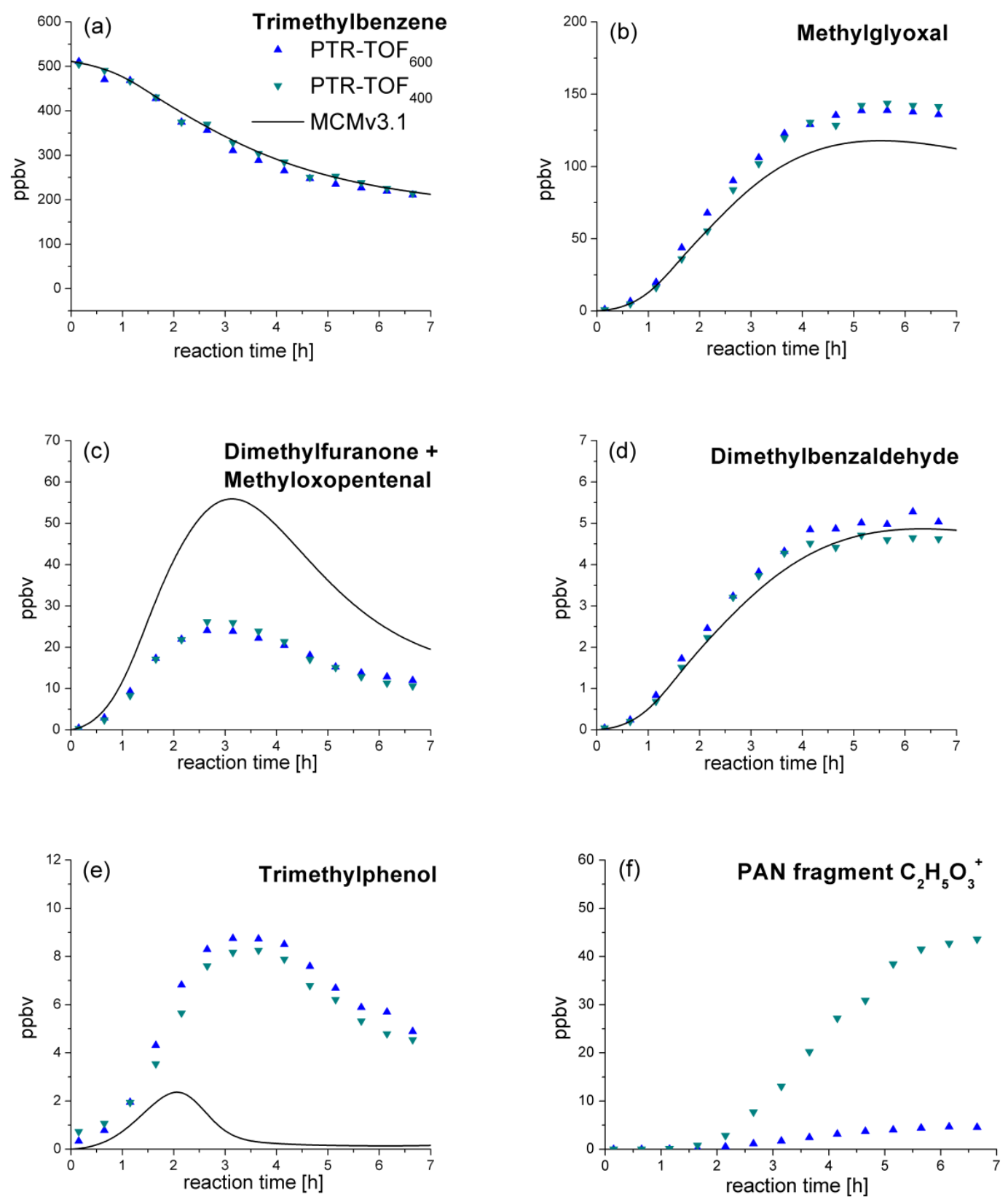

Fig. 3. Time evolution of (a) TMB and (b)-(f) selected TMB degradation products as measured during experiment 1 a (PTR-TOF 600$)$ and experiment $1 \mathrm{~b}\left(\mathrm{PTR}-\mathrm{TOF}_{400}\right)$. The black line illustrates corresponding MCMv3.1 predictions.

The measured $\mathrm{C}_{3}$ reaction products shown in panel (b) are dominated by methylglyoxal. Measured data are in good agreement with model expectations. About $60 \mathrm{ppbC}$ of the higher $\mathrm{C}_{3}$ product signal can be explained by the difference of the measured and the expected methylglyoxal concentration.
Panels (c) and (d) depict the temporal evolutions of the measured and modeled $\mathrm{C}_{4}$ and $\mathrm{C}_{5}$ TMB degradation products. MCMv3.1 simulations predict only low $\mathrm{C}_{4}$ - and $\mathrm{C}_{5}$ - product yields. By comparing PTR-TOF 600 and PTR$\mathrm{TOF}_{400}$ data, it is obvious that more $\mathrm{C}_{4}$ but less $\mathrm{C}_{5}$ compounds are measured in the PTR-TOF 600 mode. This suggests that different drift tube settings lead to different fragmentation pathways and supports the conclusion that some of the measured $\mathrm{C}_{4}$ and $\mathrm{C}_{5}$ compounds are fragments from 

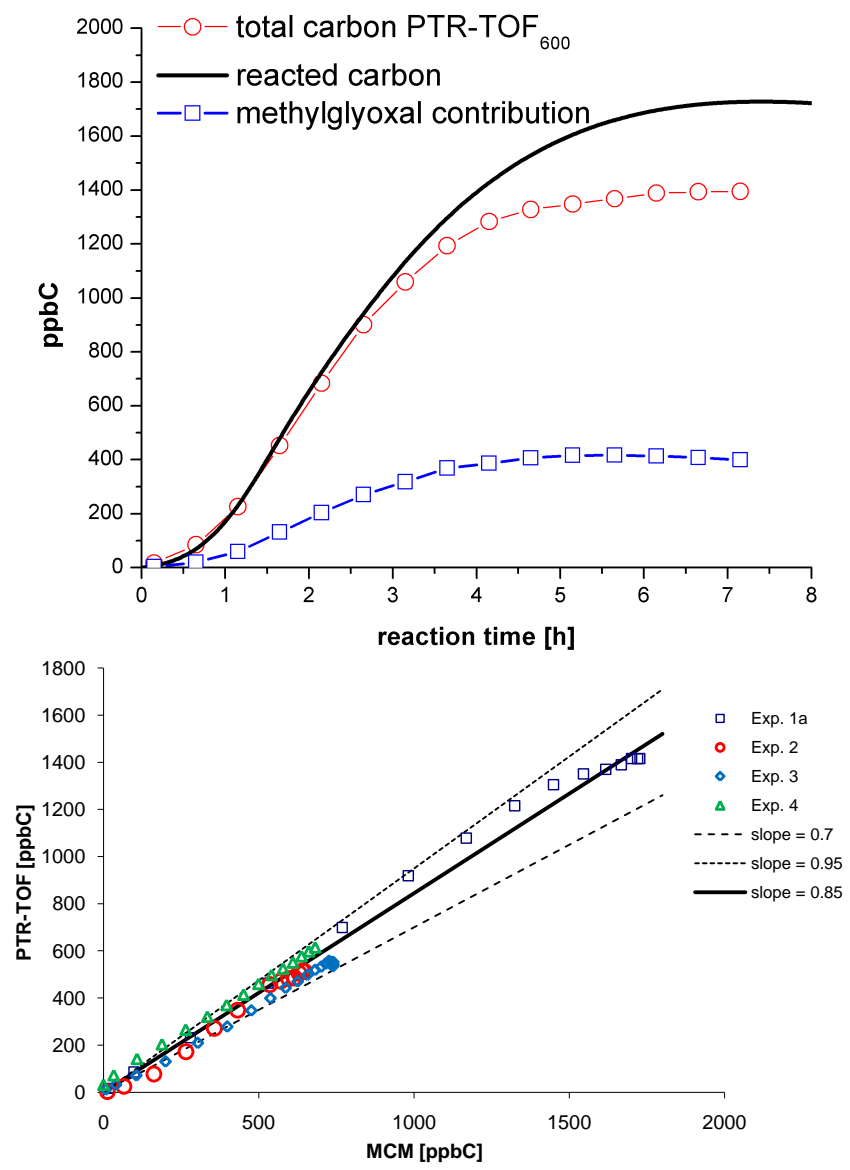

Fig. 4. (a) Time evolution of the total carbon concentration measured in all TMB degradation products (major contribution from methylglyoxal shown individually) and the available amount of carbon from TMB degradation. (b) Linear regression plot of measured versus MCMv3.1 modeled total carbon formed during TMB oxidation.

molecules with higher carbon numbers. It is interesting to note that the sum of $\mathrm{C}_{4}$ and $\mathrm{C}_{5}$ compounds is in fairly good agreement for the PTR-TOF 400 and PTR-TOF 600 modes. $\mathrm{C}_{6}$ and $\mathrm{C}_{9}$ compounds measured by PTR-TOF in both operation modes compare very well, as shown in panels (e) and (f), respectively. MCMv3.1 calculations predict significantly more $\mathrm{C}_{6}$ and $\mathrm{C}_{9}$ compounds than observed. The measured first generation ring-opening products $\mathrm{C}_{6} \mathrm{H}_{9} \mathrm{O}_{2}^{+}$(dimethylfuranone, methyloxopentenal) are lower than model predictions. The biggest MCMv3.1 contribution on $\mathrm{C}_{6}$ arises from oxopropanyl oxopropanoate $\left(\mathrm{C}_{6} \mathrm{H}_{8} \mathrm{O}_{4}\right)$, a product of dimethylfuranone, with an expected maximum level of $306 \mathrm{ppbC}$. This ester is expected to fragment upon protonation (see Supplement). Between 5-10 ppbC of the protonated compound $\left(\mathrm{C}_{6} \mathrm{H}_{9} \mathrm{O}_{4}^{+}\right)$were detected for both the PTR-TOF 600 and the PTR-TOF 400 condition. The measurements also show only minor contributions from nitrogen containing compounds.
The largest contributors to measured $\mathrm{C}_{9}$ compounds are from $\mathrm{C}_{9} \mathrm{H}_{11} \mathrm{O}^{+}$(3,5-dimethylbenzaldehyde) and $\mathrm{C}_{9} \mathrm{H}_{13} \mathrm{O}^{+}(2,4,6-$ trimethylphenol) which are both not expected to fragment upon protonation. However, these two species make up only $7 \%$ of the first generation products according to MCMv3.1 (see Fig. 1). From the less stable ring-retaining "peroxidebicyclic" compounds, only a small fraction is expected not to fragment upon protonation. These compounds may have partially fragmented to the $\mathrm{C}_{4}$ and $\mathrm{C}_{5}$ ions discussed above.

Figure 6a compares the gas phase total oxygen-to-carbon ratios $\left(\mathrm{O}: \mathrm{C}_{\mathrm{gas}}\right)$ measured by PTR-TOF and simulated with the MCMv3.1. Similar to the total measured products depicted in Fig. 4, good agreement between measurements and MCMv3.1 simulation was found for the first $4 \mathrm{~h}$ of reaction. Figure $6 \mathrm{~b}$ illustrates the time evolution of the individual highly mass resolved PTR-TOF signals with different O:C ratios that contribute to the measured total $\mathrm{O}: \mathrm{C}$ ratio. The $\mathrm{O}: \mathrm{C}_{\text {gas }}$ ratios for experiments $1 \mathrm{a}, 2,3$, and 4 are depicted in Fig. 7a. Differences in the temporal evolution of the O:C $\mathrm{C}_{\text {gas }}$ ratios are clearly discernible. Experiment $1 \mathrm{a}$ and experiment 2 started with similar $\mathrm{TMB} / \mathrm{NO}_{\mathrm{x}}$ ratios but different initial concentrations (see Table 1). O: $\mathrm{C}_{\text {gas }}$ develops similarly over time reaching maximum levels of about 0.30 after $7 \mathrm{~h}$ of reaction. $\mathrm{O}: \mathrm{C}_{\mathrm{gas}}$ measured during experiment 3 (high initial $\mathrm{NO}_{\mathrm{x}}$ ) shows a similar initial behavior compared to experiment $1 \mathrm{a}$ up to $3 \mathrm{~h}$ of reaction but then continues to rise. In experiment $4 \mathrm{a}$ (HONO addition), oxidation starts immediately with $\mathrm{O}: \mathrm{C}_{\text {gas }}$ reaching a maximum of 0.45 after $7 \mathrm{~h}$ of reaction. Figure $7 \mathrm{~b}$ again shows that the measured $\mathrm{O}: \mathrm{C}_{\mathrm{gas}}$ ratios are very close to the modeled ones. A linear regression of all data yields a slope of 0.94 . The upper and lower bounds have slopes of 1.05 and 0.75 , respectively. In the PTR-TOF protonation may lead to loss of oxygen (e.g. via $\mathrm{H}_{2} \mathrm{O}$ loss following protonation of an -OH group or $\mathrm{HNO}_{3}$ loss following protonation of an $-\mathrm{ONO}_{2}$ group). The good agreement of PTR-TOF measured O:C ratios with the MCMv3.1 calculations suggests that this effect is obviously small or counterbalanced by the loss of carbon.

\subsection{SOA analysis}

Integrating the aerosol signal over the whole desorption experiment between 4.5 and $6 \mathrm{~h}$ of reaction time results in a total SOA concentration of $14.8 \mu \mathrm{g} \mathrm{m}^{-3}$. With a scanning mobility particle sizer $23.01 \mu \mathrm{g} \mathrm{m}^{-3}$ of SOA (aerosol density $=1.4 \mathrm{~g} \mathrm{~cm}^{-3}$, Alfarra et al., 2006) were measured during the same period. This results in an aerosol fraction of $64.3 \%$ that was detected by PTR-TOF.

The measured atomic $\mathrm{O}: \mathrm{C}_{\mathrm{SOA}}$ ratios of the collected and thermally desorbed SOA were between 0.57 and 0.51 (Table 4). This is somewhat higher than the atomic O:C ratios measured by HR TOF-AMS $(\mathrm{O}: \mathrm{C}=0.45$; Jimenez et al., 2009). O: $\mathrm{C}_{\mathrm{SOA}}$ slightly decreases towards higher desorption temperatures. The degree of oxidation is more than double the one observed for the total gas phase $\mathrm{O}: \mathrm{C}_{\mathrm{gas}}$ (including 

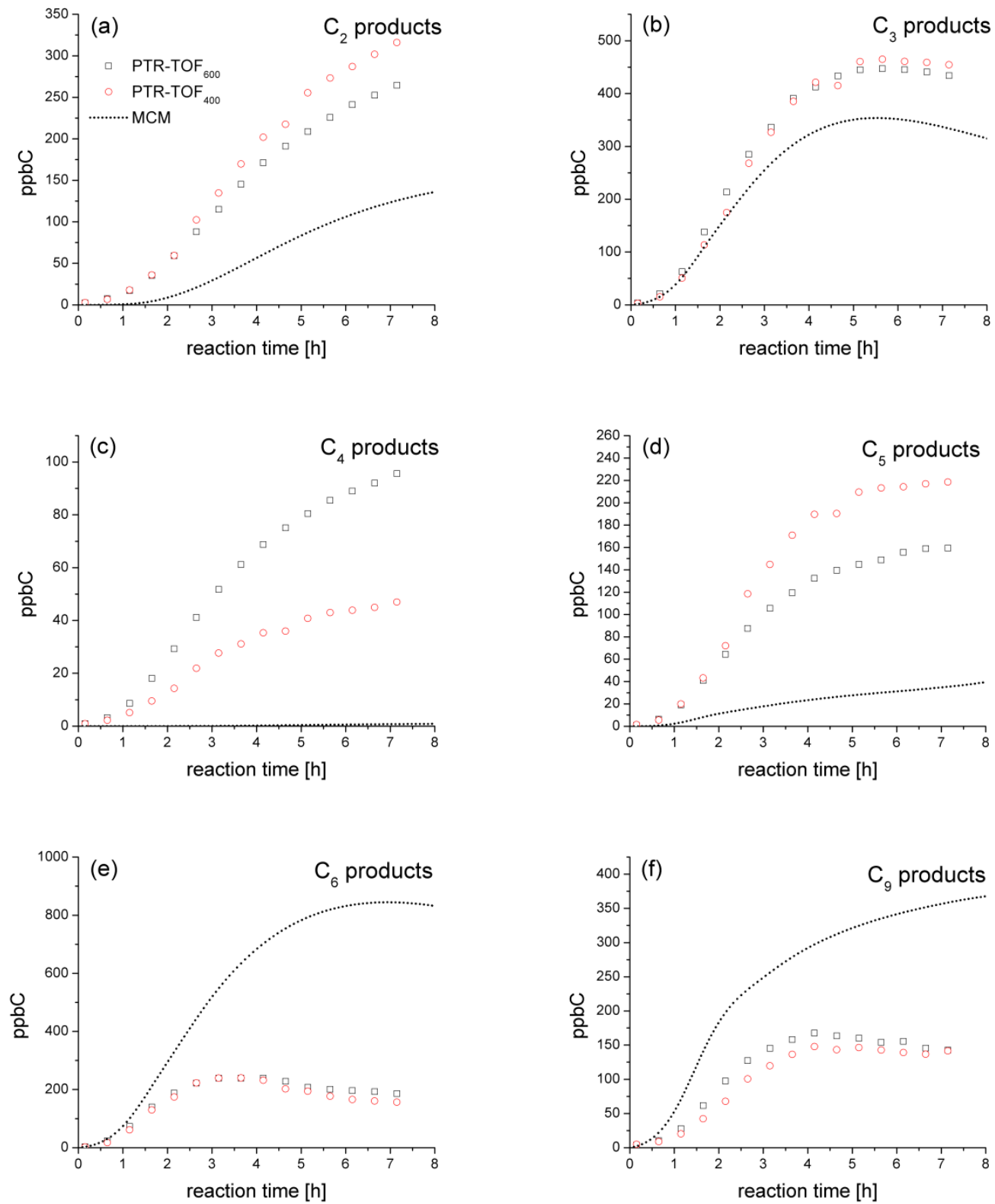

Fig. 5. Time evolution of $\mathrm{C}_{2}, \mathrm{C}_{3}, \mathrm{C}_{4}, \mathrm{C}_{5}, \mathrm{C}_{6}$, and $\mathrm{C}_{9} \mathrm{TMB}$ degradation products as measured by PTR-TOF 600 and PTR-TOF 400 and predicted by the MCMv3.1

TMB) at the same reaction time of experiment $1 \mathrm{~b}$, but a bit lower than $\mathrm{O}: \mathrm{C}$ observed for the gas phase products only $(\mathrm{O}: \mathrm{C}=0.69$, excluding $\mathrm{TMB})$. It is likely that $\mathrm{O}: \mathrm{C}_{\mathrm{SOA}}$ is underestimated due to fragmentation as discussed for the gas phase results. It is also possible that from some species $\mathrm{H}_{2} \mathrm{O}$ and $\mathrm{CO}_{2}$ is split off at the highest temperature which would lead to a further underestimation of the $\mathrm{O}: \mathrm{C}$ ratio.

Figure 8 depicts the relative distribution of carbon in the gas phase and in SOA according to the carbon atom number $n_{\mathrm{C}}$ (a) and according to the oxygen atom number $n_{\mathrm{O}}$ (b). A comparison of the gas phase product (excluding TMB) and
SOA distribution shows a higher average carbon number per molecule and a higher oxygen amount in the SOA. For the three temperature desorption steps, the biggest differences in the carbon number are visible for the $\mathrm{C}_{9}$ compounds. Relative $\mathrm{C}_{9}$ intensities rise towards higher temperatures. While $\mathrm{O}: \mathrm{C}_{\mathrm{SOA}}$ slightly decreases towards higher desorption temperatures, the oxygen number distribution gets shifted towards higher oxygen numbers. This suggests that the more volatile fraction is composed of shorter and more oxidized molecules while the low volatility fraction contains longer chained but somewhat lower oxidation state molecules. 

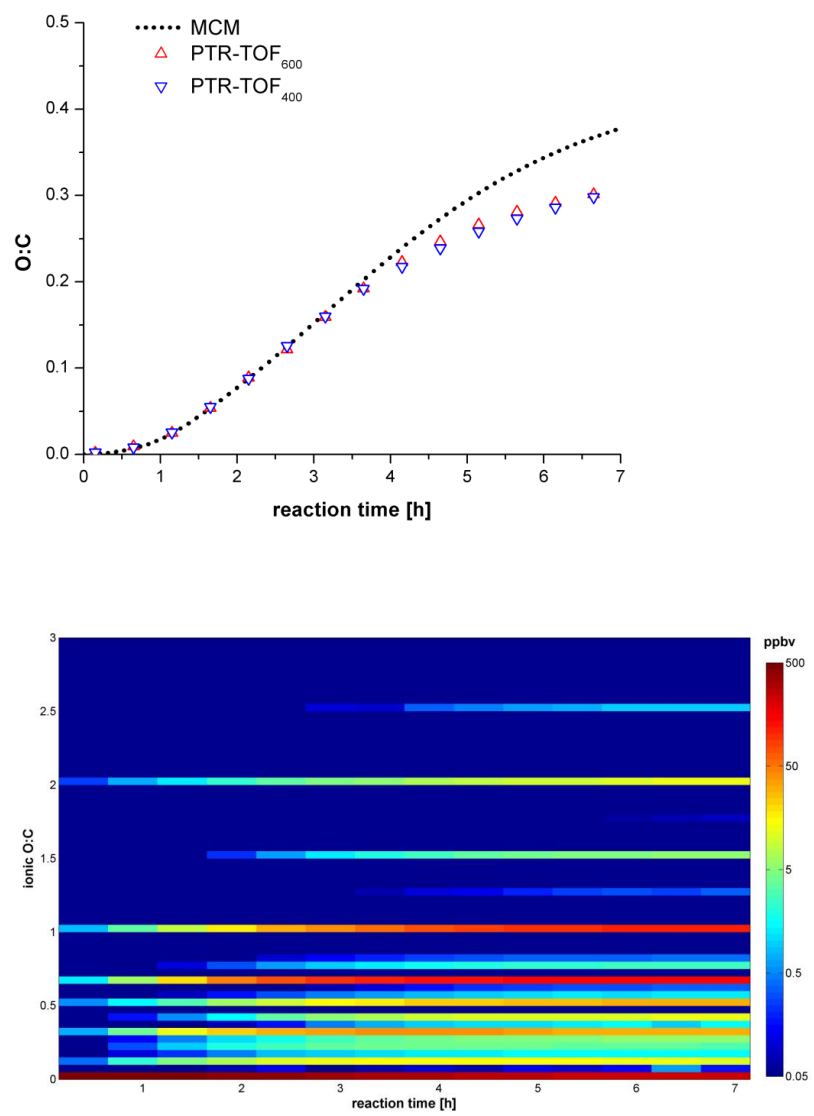

Fig. 6. (a) Measured total O:C ratios $\left(\mathrm{PTR}-\mathrm{TOF}_{600}\right.$ and PTR$\mathrm{TOF}_{400}$; data from experiments $1 \mathrm{a}$ and $1 \mathrm{~b}$, respectively) compared with the MCMv3.1 model output. (b) Time evolution of individual highly mass resolved PTR-TOF signals with different O:C ratios as observed during experiment $1 \mathrm{a}$.

Table 4. Overview of total O:C ratios measured in the particle phase $\left(\mathrm{O}: \mathrm{C}_{\mathrm{SOA}}\right.$ ), in the total gas phase (including TMB; $\mathrm{O}: \mathrm{C}_{\text {gas }}$ ) and for the gas phase products (excluding TMB, O:C) after $4 \mathrm{~h}$ of reaction during experiment $1 \mathrm{~b}$.

\begin{tabular}{lrcc}
\hline desorption temperature $\left({ }^{\circ} \mathrm{C}\right)$ & 75 & 100 & 125 \\
\hline O:C & 0.57 & 0.54 & 0.51 \\
O:C $\mathrm{C}_{\text {gas }}$ (total gas phase) & 0.26 & \\
O:C (gas phase products) & 0.67 & \\
\hline
\end{tabular}

\subsection{Van Krevelen diagram}

Figure 9 illustrates the Van Krevelen diagram which includes data from four gas phase measurements (experiments 1a, 2, 3,4 ) and from one SOA experiments (experiment 1b). Data from all experiments cover a narrow range in the Van Krevelen diagram. Starting with an $\mathrm{O}: \mathrm{C}$ ratio of 0 and an $\mathrm{H}: \mathrm{C}$ ratio of 1.33 (with TMB having the molecular formula $\mathrm{C}_{9} \mathrm{H}_{12}$ ), the
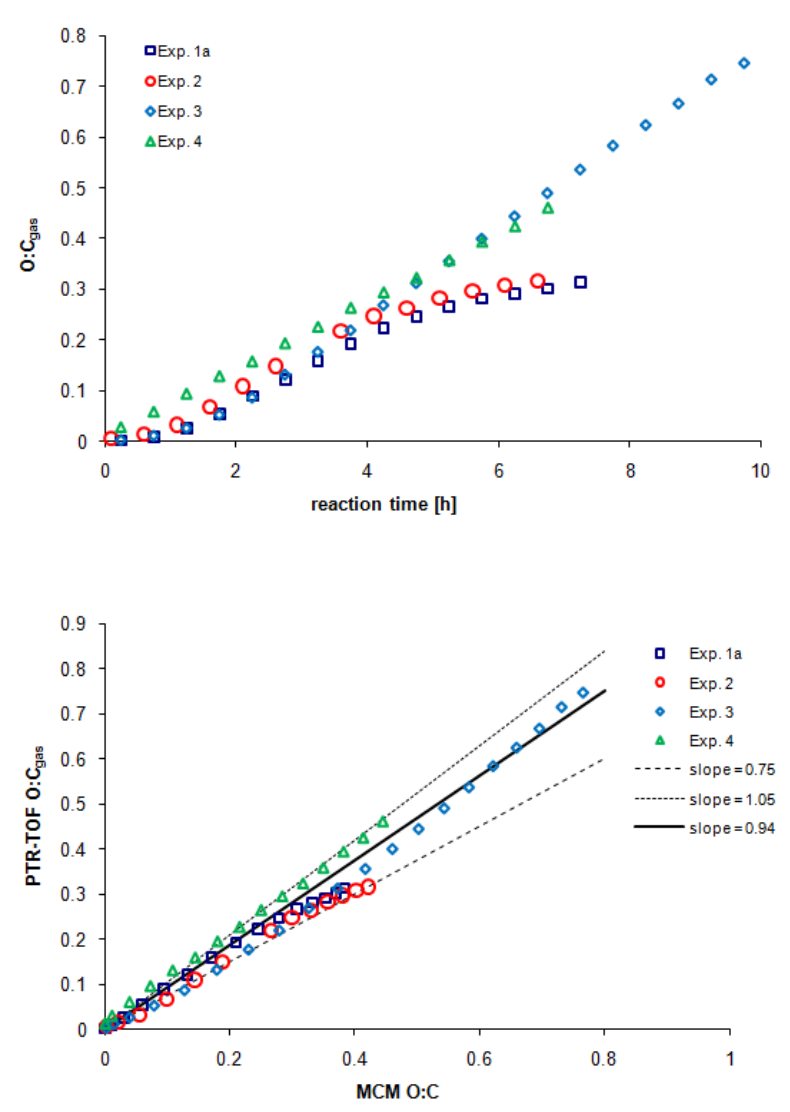

Fig. 7. (a) Time evolution of total O: $\mathrm{C}_{\text {gas }}$ ratios measured with the PTR-TOF 600 during experiments 1a, 2, 3 and 4.(b) Linear regression plot of $\mathrm{O}: \mathrm{C}$ ratio measurements versus $\mathrm{MCMv3.1}$ simulations.

$\mathrm{O}: \mathrm{C}$ ratio increases during the photo-oxidation process while the $\mathrm{H}: \mathrm{C}$ ratio stays about constant. A maximum $\mathrm{H}: \mathrm{C}$ ratio of 1.49 was measured for the particulate phase at $75^{\circ} \mathrm{C}$ desorption temperature. The gas-phase oxidation is characterized by a slope of $\sim 0$ in the Van Krevelen diagram as opposed to the slope of -1 typically found for organic aerosol (Heald et al., 2010). Particles show a similar H:C ratio (except for low desorption temperature), but a higher $\mathrm{O}: \mathrm{C}$ ratio. The position of the particle measurements in the Van Krevelen diagram is in agreement to the findings of Heald et al. (2010).

\subsection{Carbon oxidation state}

Figure 10 visualizes the $\overline{\mathrm{OS}}_{\mathrm{C}}-n_{\mathrm{C}}$ positions of all detected $\mathrm{m} / \mathrm{z}$ ratios measured in the gas phase and all $\mathrm{m} / \mathrm{z}$ measured from the SOA analysis. With a few exceptions all of the gas phase species are located to the right of TMB and towards higher $\overline{\mathrm{OS}}_{\mathrm{C}}$ (upper right area). In the particle phase also species with higher $n_{\mathrm{c}}$ than TMB were observed filling the space towards the upper left. Figure 10 also depicts the evolution of the average $\overline{\mathrm{OS}}_{\mathrm{C}}$ of experiments 1a, 2, 3, 4 within the first seven hours of photo-oxidation in the $\overline{\mathrm{OS}}_{\mathrm{C}}-n_{\mathrm{C}}$ space. 

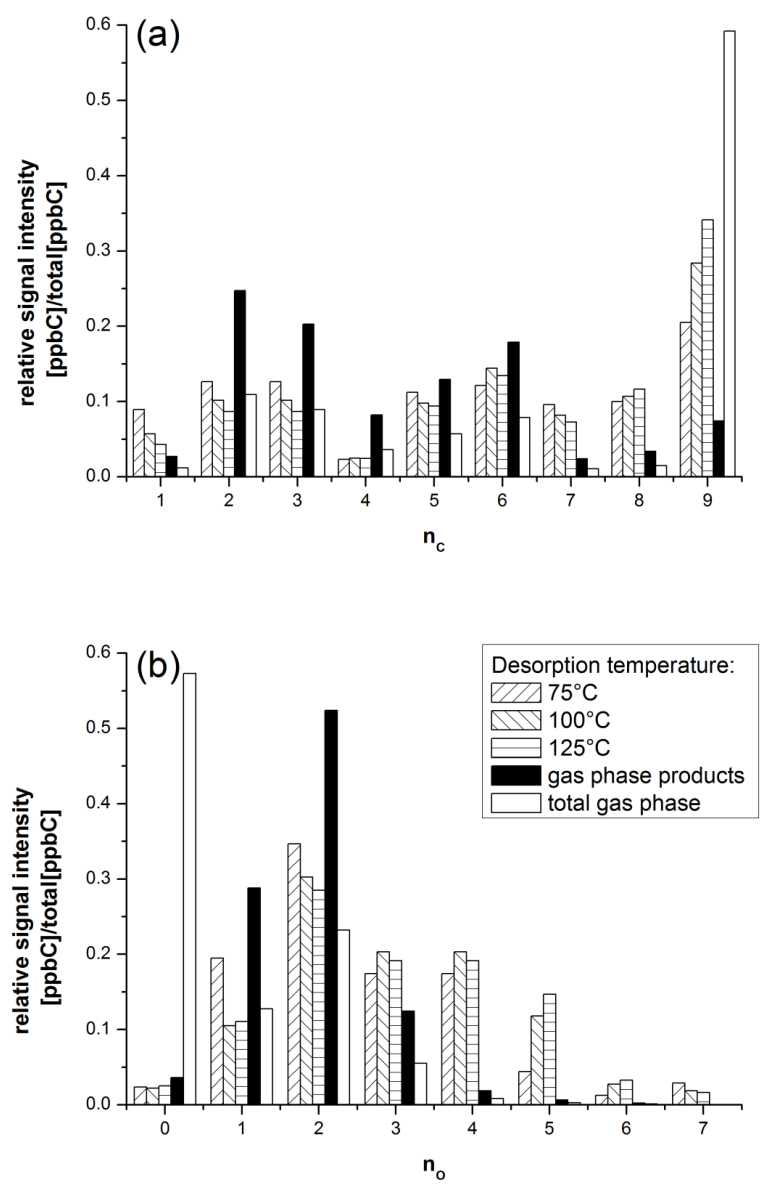

Fig. 8. Relative distribution of total carbon in thermally desorbed SOA $\left(75^{\circ} \mathrm{C}, 100^{\circ} \mathrm{C}, 125^{\circ} \mathrm{C}\right)$ and in the gas phase (products only and total gas phase including TMB) according to the carbon atom number (a) and according to the oxygen atom number (b). SOA and gas phase samples were taken between 4.5 and $6 \mathrm{~h}$ of reaction time (experiment $1 \mathrm{~b})$.

Starting at $\overline{\mathrm{OS}}_{\mathrm{C}-n_{\mathrm{C}}}$ of TMB the oxidation trajectories move towards higher $\overline{\mathrm{OS}}_{\mathrm{C}}$ values due to functionalization and towards lower $n_{\mathrm{C}}$ due to fragmentation. The fragmentation pathway is dominant in the beginning and a stronger increase of $\overline{\mathrm{OS}}_{\mathrm{C}}$ occurs later. This may be specific to aromatic compounds as compared to long chain hydrocarbons or terpenes.

Experiment 1a and 2 (similar $\mathrm{VOC} / \mathrm{NO}_{\mathrm{x}}$ ratios) show a similar $\overline{\mathrm{OS}}_{\mathrm{C}}$ after $7 \mathrm{~h}$ of experiment $\left(\overline{\mathrm{OS}}_{\mathrm{C}}^{\max } \sim-0.7\right)$, but experiment 2 shows a higher degree of fragmentation. As seen in Fig. 7, experiment 2 also has a higher O:C ratio. The high $\mathrm{NO}_{\mathrm{x}}$ experiment 3 shows the highest $\overline{\mathrm{OS}}_{\mathrm{C}}$ value after $7 \mathrm{~h}$ of reaction $\left(\overline{\mathrm{OS}}_{\mathrm{C}}^{\max }=-0.39\right)$ with an $n_{\mathrm{C}}$ of 3.4. Experiment 4 shows a quite similar initial behavior compared to experiment 2 , but ends at a higher $\overline{\mathrm{OS}}_{\mathrm{C}}$ value of about $\overline{\mathrm{OS}}_{\mathrm{C}}^{\mathrm{max}}=-0.5$. In addition, the fragmentation is further developed to an average $n_{\mathrm{C}}$ of 3.3 .

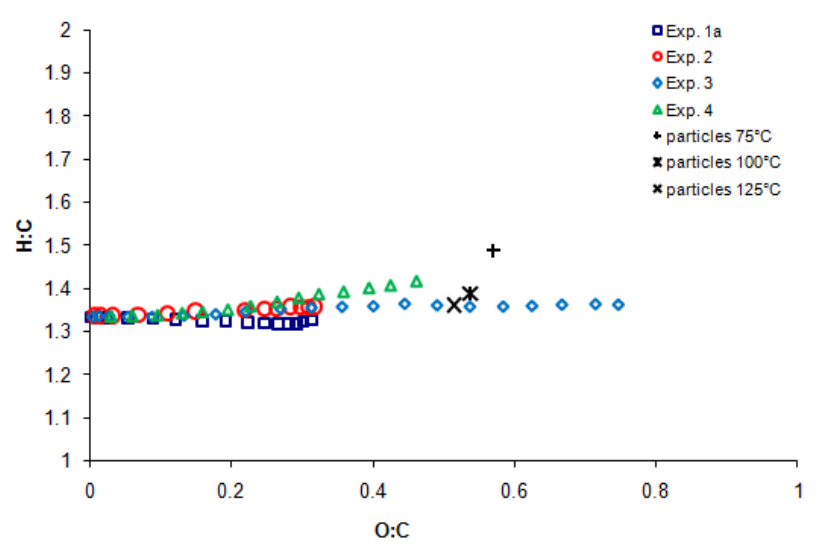

Fig. 9. Van Krevelen diagram including data from experiments 1a, 2, 3 and 4 (gas phase) and experiment $1 \mathrm{~b}$ (SOA).

Comparison of experiment 1a with the SOA samples taken after $4 \mathrm{~h}$ of reaction time shows a higher $\overline{\mathrm{OS}}_{\mathrm{C}}^{\mathrm{SOA}}$ at all temperature steps $\left(\overline{\mathrm{OS}}_{\mathrm{C}}^{\mathrm{SOA}} \sim-0.34\right.$ to -0.31$)$ than for the gas phase species $\left(\overline{\mathrm{OS}}_{\mathrm{C}}^{4 \mathrm{~h}}=-0.87, n_{\mathrm{C}}^{4 \mathrm{~h}}=5.5\right)$. The most volatile SOA evaporated at $75^{\circ} \mathrm{C}$ shows the lowest $n_{\mathrm{C}}=4.7$, whereas at $100^{\circ} \mathrm{C}$ and $125^{\circ} \mathrm{C}$ a $n_{\mathrm{C}}$ of between 5.5 and 5.9 is measured. According to Kroll et al. (2011), the position of the $100^{\circ} \mathrm{C}$ and the $125^{\circ} \mathrm{C}$ samples in the $\overline{\mathrm{OS}}_{\mathrm{C}}$ vs. $n_{\mathrm{C}}$ space are in the range, where fresh SOA is expected $\left(\overline{\mathrm{OS}}_{\mathrm{C}}=-0.5-0\right.$; data measured by AMS, Paulot et al., 2009).

In Fig. 10 it is also visible that species with more than 9 carbons were detected in the particle phase indicating oligomerization reactions.

\section{Summary and conclusion}

In the present study, we evaluate the performance of a high resolution PTR-TOF for environmental chamber measurements. The measured amount of carbon was only $\sim 15 \%$ lower than the amount of carbon available from the TMB degradation. Time series of $\mathrm{C}_{3}, \mathrm{C}_{6}$ and $\mathrm{C}_{9}$ products compared well for the PTR-TOF 600 and PTR-TOF 400 operation modes but showed significant differences to MCMv3.1 predictions. The observation of $\mathrm{C}_{4}$ and $\mathrm{C}_{5}$ products was attributed to ionic fragmentation processes. The measured total $\mathrm{O}: \mathrm{C}$ ratio in the gas phase was slightly lower than $\mathrm{MCMv3.1}$ predictions (0.75 to 1.05$)$. PTR-TOF measurements also allowed a direct determination of the average carbon oxidation state $\overline{\mathrm{OS}}_{\mathrm{C}}$ as a function of the average carbon number $n_{\mathrm{c}}$. Photo-oxidation of TMB is characterized by strong initial fragmentation followed by an increase in $\overline{\mathrm{OS}}_{\mathrm{C}}$ during the later phase of the photo-oxidation experiments. Compared to gas samples at the same time of reaction, SOA sampled by filters and measured after thermal desorption was characterized by a larger average carbon skeleton and higher 


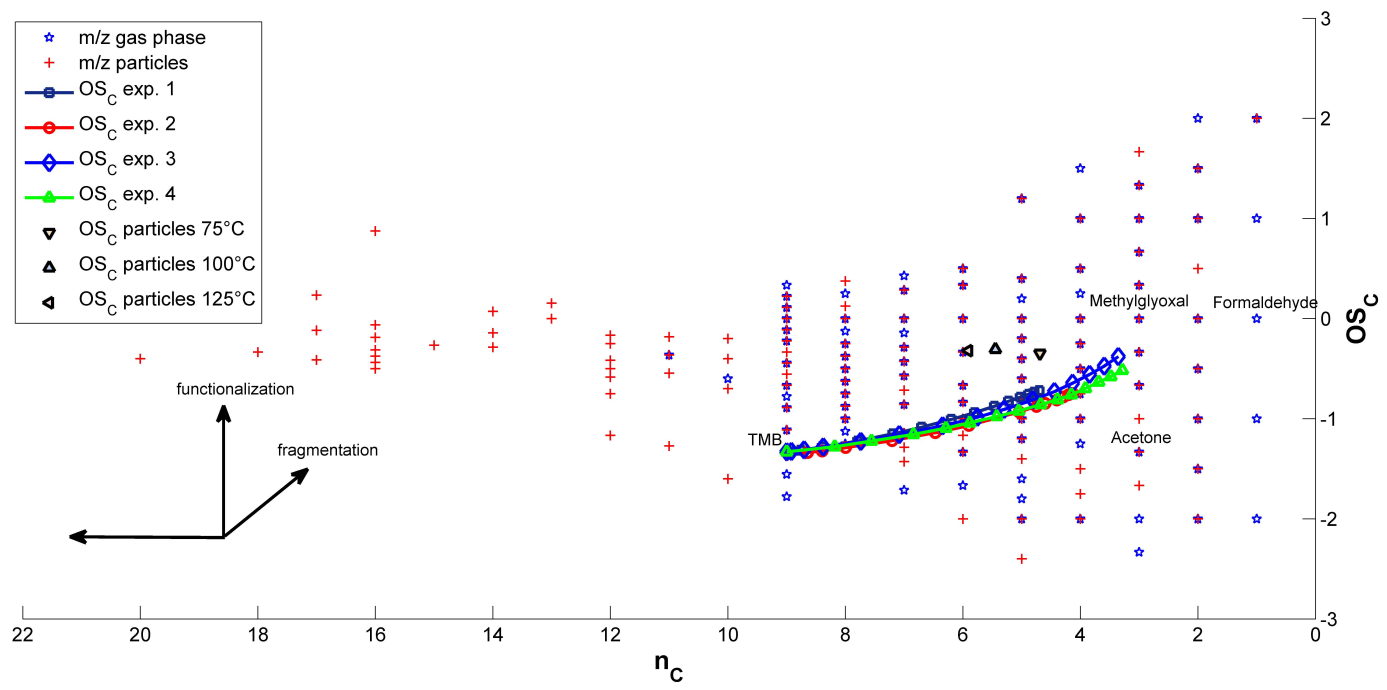

Fig. 10. Data from the first $7 \mathrm{~h}$ of gas-phase measurements (experiments 1a, 2, 3 and 4) and SOA measurements (experiment 1b) depicted in the $\overline{\mathrm{OS}}_{\mathrm{C}}-n_{\mathrm{C}}$ space. Blue stars depict the $\overline{\mathrm{OS}}_{\mathrm{C}}-n_{\mathrm{C}}$ position of all detected $m / z$ signals measured in the gas phase and red crosses indicate all $\mathrm{m} / \mathrm{z}$ signals detected in the SOA study. Solid lines indicate the evolution of the average $\overline{\mathrm{OS}}_{C}$ during the course of the photo-oxidation experiments. Black symbols show the average $\overline{\mathrm{OS}}_{\mathrm{C}}$ in the particle phase as measured at different desorption temperatures (experiment $1 \mathrm{~b}$ ).

$\overline{\mathrm{OS}}_{\mathrm{C}}$. Observed $\overline{\mathrm{OS}}_{\mathrm{C}}$ values in the range between of -0.34 to -0.31 were in agreement with reported numbers for fresh SOA.

The obtained results demonstrate that high resolution PTR-TOF is a valuable method to study the oxidation of organic compounds. Fragmentation of ions upon protonation (e.g. loss of hydroxy, hydroperoxy or nitrooxy groups) is problematic, but for the TMB system the carbon budget and $\mathrm{O}: \mathrm{C}$ ratios were still captured fairly well. This needs to be further investigated for other precursors.

\section{Supplementary material related to this article is available online at: http://www.atmos-chem-phys.net/12/829/2012/ acp-12-829-2012-supplement.pdf.}

Acknowledgements. This work was supported by the Swiss National Science Foundation, the EC project EUROCHAMP FP6-505968, the Austrian Research Funding Association (FFG; Basisprogramm-Brückenschlag 1, P.-Nr. 810074) and the Austrian Science Fund (FWF; L518-N20). Armin Wisthaler and Martin Graus were supported by ESF-INTROP exchange grants 1172 and 1185, respectively. The authors thank Andreas Mauracher and Michael Probst for their help in calculating quantum chemical properties of uncalibrated compounds.

Edited by: A. Kiendler-Scharr

\section{References}

Aiken, A. C., Decarlo, P. F., Kroll, J. H., Worsnop, D. R., Huffman, J. A., Docherty, K. S., Ulbrich, I. M., Mohr, C., Kimmel, J. R., Sueper, D., Sun, Y., Zhang, Q., Trimborn, A., Northway, M., Ziemann, P. J., Canagaratna, M. R., Onasch, T. B., Alfarra, M. R., Prevot, A. S. H., Dommen, J., Duplissy, J., Metzger, A., Baltensperger, U., and Jimenez, J. L.: O/C and OM/OC ratios of primary, secondary, and ambient organic aerosols with highresolution time-of-flight aerosol mass spectrometry, Environ. Sci. Technol., 42, 4478-4485, doi:10.1021/es703009q, 2008.

Alfarra, M. R., Paulsen, D., Gysel, M., Garforth, A. A., Dommen, J., Prévôt, A. S. H., Worsnop, D. R., Baltensperger, U., and Coe, H.: A mass spectrometric study of secondary organic aerosols formed from the photooxidation of anthropogenic and biogenic precursors in a reaction chamber, Atmos. Chem. Phys., 6, 5279-5293, doi:10.5194/acp-6-5279-2006, 2006.

Aoki, N., Inomata, S., and Tanimoto, H.: Detection of C-1C-5 alkyl nitrates by proton transfer reaction time-of-flight mass spectrometry, Int. J. Mass Spectrom., 263, 12-21, 10.1016/j.ijms.2006.11.018, 2007.

Apel, E. C., Brauers, T., Koppmann, R., Bandowe, B., Bossmeyer, J., Holzke, C., Tillmann, R., Wahner, A., Wegener, R., Brunner, A., Jocher, M., Ruuskanen, T., Spirig, C., Steigner, D., Steinbrecher, R., Alvarez, E. G., Müller, K., Burrows, J. P., Schade, G., Solomon, S. J., Ladstatter-Weissenmayer, A., Simmonds, P., Young, D., Hopkins, J. R., Lewis, A. C., Legreid, G., Reimann, S., Hansel, A., Wisthaler, A., Blake, R. S., Ellis, A. M., Monks, P. S., and Wyche, K. P.: Intercomparison of oxygenated volatile organic compound measurements at the Saphir atmosphere simulation chamber, J. Geophys. Res.-Atmos., 113, D20307, doi:10.1029/2008jd009865, 2008.

Blake, R. S., Whyte, C., Hughes, C. O., Ellis, A. M., and Monks, P. S.: Demonstration of proton-transfer reaction time-of-flight mass 
spectrometry for real-time analysis of trace volatile organic compounds, Anal. Chem., 76, 3841-3845, doi:10.1021/ac0498260, 2004.

Blake, R. S., Wyche, K. P., Ellis, A. M., and Monks, P. S.: Chemical ionization reaction time-of-flight mass spectrometry: Multireagent analysis for determination of trace gas composition, Int. J. Mass Spectrom., 254, 85-93, doi:10.1016/j.ijms.2006.05.021, 2006.

Bloss, C., Wagner, V., Bonzanini, A., Jenkin, M. E., Wirtz, K., Martin-Reviejo, M., and Pilling, M. J.: Evaluation of detailed aromatic mechanisms (MCMv3 and MCMv3.1) against environmental chamber data, Atmos. Chem. Phys., 5, 623-639, doi:10.5194/acp-5-623-2005, 2005a.

Bloss, C., Wagner, V., Jenkin, M. E., Volkamer, R., Bloss, W. J., Lee, J. D., Heard, D. E., Wirtz, K., Martin-Reviejo, M., Rea, G., Wenger, J. C., and Pilling, M. J.: Development of a detailed chemical mechanism (MCMv3.1) for the atmospheric oxidation of aromatic hydrocarbons, Atmos. Chem. Phys., 5, 641664, 2005b,

http://www.atmos-chem-phys.net/5/641/2005/.

Calvert, J. G., Atkinson, R., Becker, K. H., Kamens, R. M., Seinfeld, J. H., Wallington, T. J., and Yarwood, G.: The Mechanisms of Atmospheric Oxidation of Aromatic Hydrocarbons, Oxford University Press, Oxford, 556 pp., 2002.

D’Anna, B., Wisthaler, A., Andreasen, O., Hansel, A., Hjorth, J., Jensen, N. R., Nielsen, C. J., Stenstrom, Y., and Viidanoja, J.: Atmospheric chemistry of C-3-C-6 cycloalkanecarbaldehydes, J. Phys. Chem. A, 109, 5104-5118, doi:10.1021/jp044495g, 2005.

de Gouw, J., Warneke, C., Karl, T., Eerdekens, G., van der Veen, C., and Fall, R.: Sensitivity and specificity of atmospheric trace gas detection by proton-transfer-reaction mass spectrometry, Int. J. Mass Spectrom., 223, 365-382, 2003.

Ennis, C. J., Reynolds, J. C., Keely, B. J., and Carpenter, L. J.: A hollow cathode proton transfer reaction time of flight mass spectrometer, Int. J. Mass Spectrom., 247, 72-80, doi:10.1016/j.ijms.2005.09.008, 2005.

Graus, M., Müller, M., and Hansel, A.: High Resolution PTR-TOF: Quantification and formula confirmation of VOC in real time, J. Am. Soc. Mass. Spectr., 21/6, 10371044, doi:10.1016/j.jasms.2010.02.006, 2010.

Hallquist, M., Wenger, J. C., Baltensperger, U., Rudich, Y., Simpson, D., Claeys, M., Dommen, J., Donahue, N. M., George, C., Goldstein, A. H., Hamilton, J. F., Herrmann, H., Hoffmann, T., Iinuma, Y., Jang, M., Jenkin, M. E., Jimenez, J. L., Kiendler-Scharr, A., Maenhaut, W., McFiggans, G., Mentel, Th. F., Monod, A., Prvt, A. S. H., Seinfeld, J. H., Surratt, J. D., Szmigielski, R., and Wildt, J.: The formation, properties and impact of secondary organic aerosol: current and emerging issues, Atmos. Chem. Phys., 9, 5155-5236, doi:10.5194/acp-95155-2009, 2009.

Hansel, A. and Wisthaler, A.: A method for real-time detection of PAM, PPN and MPAN in ambient air, Geophys. Res. Lett., 27, 895-898, 2000.

Heald, C.L., Kroll, J.H., Jimenez, J.L., Docherty, K.S., DeCarlo, P.F., Aiken, A.C., Chen, Q., Martin, S.T., Farmer, D.K., and Artaxo, P.: A simplified description of the evolution of organic aerosol composition in the atmosphere, Geophys. Res. Lett., 37, L08803, doi:10.1029/2010GL042737, 2010.

Healy, R. M., Wenger, J. C., Metzger, A., Duplissy, J., Kalberer,
M., and Dommen, J.: Gas/particle partitioning of carbonyls in the photooxidation of isoprene and 1,3,5-trimethylbenzene, Atmos. Chem. Phys., 8, 3215-3230, doi:10.5194/acp-8-3215-2008, 2008.

Hellen, H., Dommen, J., Metzger, A., Gascho, A., Duplissy, J., Tritscher, T., Prevot, A. S. H., and Baltensperger, U.: Using proton transfer reaction mass spectrometry for online analysis of secondary organic aerosols, Environ. Sci. Technol., 42, 73477353, 2008.

Holzinger, R., Williams, J., Herrmann, F., Lelieveld, J., Donahue, N. M., and Röckmann, T.: Aerosol analysis using a ThermalDesorption Proton-Transfer-Reaction Mass Spectrometer (TDPTR-MS): a new approach to study processing of organic aerosols, Atmos. Chem. Phys., 10, 2257-2267, doi:10.5194/acp10-2257-2010, 2010.

Jenkin, M. E., Saunders, S. M., Wagner, V., and Pilling, M. J.: Protocol for the development of the Master Chemical Mechanism, MCM v3 (Part B): tropospheric degradation of aromatic volatile organic compounds, Atmos. Chem. Phys., 3, 181-193, doi:10.5194/acp-3-181-2003, 2003.

Jimenez, J. L., Canagaratna, M. R., Donahue, N. M., Prevot, A. S. H., Zhang, Q., Kroll, J. H., DeCarlo, P. F., Allan, J. D., Coe, H., Ng, N. L., Aiken, A. C., Docherty, K. S., Ulbrich, I. M., Grieshop, A. P., Robinson, A. L., Duplissy, J., Smith, J. D., Wilson, K. R., Lanz, V. A., Hueglin, C., Sun, Y. L., Tian, J., Laaksonen, A., Raatikainen, T., Rautiainen, J., Vaattovaara, P., Ehn, M., Kulmala, M., Tomlinson, J. M., Collins, D. R., Cubison, M. J., Dunlea, E. J., Huffman, J. A., Onasch, T. B., Alfarra, M. R., Williams, P. I., Bower, K., Kondo, Y., Schneider, J., Drewnick, F., Borrmann, S., Weimer, S., Demerjian, K., Salcedo, D., Cottrell, L., Griffin, R., Takami, A., Miyoshi, T., Hatakeyama, S., Shimono, A., Sun, J. Y., Zhang, Y. M., Dzepina, K., Kimmel, J. R., Sueper, D., Jayne, J. T., Herndon, S. C., Trimborn, A. M., Williams, L. R., Wood, E. C., Middlebrook, A. M., Kolb, C. E., Baltensperger, U., and Worsnop, D. R.: Evolution of organic aerosols in the atmosphere, Science, 326, 1525-1529, doi:10.1126/science.1180353, 2009.

Kanakidou, M., Seinfeld, J. H., Pandis, S. N., Barnes, I., Dentener, F. J., Facchini, M. C., Van Dingenen, R., Ervens, B., Nenes, A., Nielsen, C. J., Swietlicki, E., Putaud, J. P., Balkanski, Y., Fuzzi, S., Horth, J., Moortgat, G. K., Winterhalter, R., Myhre, C. E. L., Tsigaridis, K., Vignati, E., Stephanou, E. G., and Wilson, J.: Organic aerosol and global climate modelling: a review, Atmos. Chem. Phys., 5, 1053-1123, doi:10.5194/acp-5-1053-2005, 2005.

Kroll, J. H., Donahue, N. M., Jimenez, J. L., Kessler, S. H., Canagaratna, M. R., Wilson, K. R., Altieri, K. E., Mazzoleni, L. R., Wozniak, A. S., Bluhm, H., Mysak, E. R., Smith, J. D., Kolb, C. E., and Worsnop, D. R.: Carbon oxidation state as a metric for describing the chemistry of atmospheric organic aerosol, Nature Chemistry, 3, 133-139, doi:10.1038/NCHEM.948, 2011.

Lanz, V. A., Alfarra, M. R., Baltensperger, U., Buchmann, B., Hueglin, C., and Prévôt, A. S. H.: Source apportionment of submicron organic aerosols at an urban site by factor analytical modelling of aerosol mass spectra, Atmos. Chem. Phys., 7, 1503-1522, doi:10.5194/acp-7-1503-2007, 2007.

Lindinger, W., Hansel, A., and Jordan, A.: On-line monitoring of volatile organic compounds at pptv levels by means of protontransfer-reaction mass spectrometry (PTR-MS) medical appli- 
cations, food control and environmental research, Int. J. Mass Spectrom., 173, 191-241, 1998.

Matsunaga, A. and Ziemann, P. J.: Gas-Wall Partitioning of Organic Compounds in a Teflon Film Chamber and Potential Effects on Reaction Product and Aerosol Yield Measurements, Aerosol Sci. Tech., 44, 881-892, 2010.

Müller, M., Graus, M., Ruuskanen, T. M., Schnitzhofer, R., Bamberger, I., Kaser, L., Titzmann, T., Hörtnagl, L., Wohlfahrt, G., Karl, T., and Hansel, A.: First eddy covariance flux measurements by PTR-TOF, Atmos. Meas. Tech., 3, 387-395, doi:10.5194/amt-3-387-2010, 2010.

Metzger, A., Dommen, J., Gaeggeler, K., Duplissy, J., Prevot, A. S. H., Kleffmann, J., Elshorbany, Y., Wisthaler, A., and Baltensperger, U.: Evaluation of 1,3,5 trimethylbenzene degradation in the detailed tropospheric chemistry mechanism, MCMv3.1, using environmental chamber data, Atmos. Chem. Phys., 8, 6453-6468, doi:10.5194/acp-8-6453-2008, 2008.

Molina, L. T., Kolb, C. E., de Foy, B., Lamb, B. K., Brune, W. H., Jimenez, J. L., Ramos-Villegas, R., Sarmiento, J., ParamoFigueroa, V. H., Cardenas, B., Gutierrez-Avedoy, V., and Molina, M. J.: Air quality in North America's most populous city overview of the MCMA-2003 campaign, Atmos. Chem. Phys., 7, 2447-2473, doi:10.5194/acp-7-2447-2007, 2007.

Paulot, F., Crounse, J. D., Kjaergaard, H. G., Kroll, J. H., Seinfeld, J. H., and Wennberg, P. O.: Isoprene photooxidation: new insights into the production of acids and organic nitrates, Atmos. Chem. Phys., 9, 1479-1501, doi:10.5194/acp-9-1479-2009, 2009.

Paulsen, D., Dommen, J., Kalberer, M., Prevot, A. S. H., Richter, R., Sax, M., Steinbacher, M., Weingartner, E., and Baltensperger, U.: Secondary organic aerosol formation by irradiation of 1,3,5trimethylbenzene- $\mathrm{NO}_{\mathrm{x}}-\mathrm{H}_{2} \mathrm{O}$ in a new reaction chamber for atmospheric chemistry and physics, Environ. Sci. Technol., 39, 2668-2678, 2005.
Perring, A. E., Wisthaler, A., Graus, M., Wooldridge, P. J., Lockwood, A. L., Mielke, L. H., Shepson, P. B., Hansel, A., and Cohen, R. C.: A product study of the isoprene+NO3 reaction, Atmos. Chem. Phys., 9, 4945-4956, doi:10.5194/acp-9-4945-2009, 2009.

Praplan, A. P., Hegyi-Gaeggeler, K., Barmet, P., Dommen, J., and Baltensperger, U.: Manuscript in prepapration, 2012.

Wisthaler, A., Jensen, N. R., Winterhalter, R., Lindinger, W., and Hjorth, J.: Measurements of acetone and other gas phase product yields from the $\mathrm{OH}$-initiated oxidation of terpenes by proton-transfer-reaction mass spectrometry (PTR-MS), Atmos. Environ., 35, 6181-6191, doi:10.1016/S1352-2310(01)00385-5, 2001.

Wyche, K. P., Monks, P. S., Ellis, A. M., Cordell, R. L., Parker, A. E., Whyte, C., Metzger, A., Dommen, J., Duplissy, J., Prevot, A. S. H., Baltensperger, U., Rickard, A. R., and Wulfert, F.: Gas phase precursors to anthropogenic secondary organic aerosol: detailed observations of 1,3,5trimethylbenzene photooxidation, Atmos. Chem. Phys., 9, 635665, doi:10.5194/acp-9-635-2009, 2009.

Tanimoto, H., Aoki, N., Inomata, S., Hirokawa, J., and Sadanaga, Y.: Development of a PTR-TOFMS instrument for real-time measurements of volatile organic compounds in air, Int. J. Mass Spectrom., 263, 1-11, doi:10.1016/j.ijms.2007.01.009, 2007.

Thornberry, T., Murphy, D. M., Thomson, D. S., de Gouw, J., Warneke, C., Bates, T. S., Quinn, P. K., and Coffman, D.: Measurement of aerosol organic compounds using a novel collection/thermal-desorption PTR-ITMS instrument, Aerosol Sci. Technol., 43, 486-501, 2009.

Van Krevelen, D. W.: Graphical-statistical method for the study of structure and reaction processes of coal, Fuel, 29, 269-84, 1950. 